\title{
COMMENTS
}

\section{THE DARKER SIDE OF NONPROFITS: WHEN CHARITIES \\ AND SOCIAL WELFARE GROUPS BECOME \\ POLITICAL SLUSH FUNDS}

\author{
ROBERT PAUL MEIER ${ }^{\dagger}$
}

\section{INTRODUCTION: CLINTON'S BILTMORE BONANZA}

The 1996 general election was only two weeks away. ${ }^{1}$ Many of Florida's Democratic faithful had gathered at the Biltmore Hotel in Coral Gables for a prominent fundraiser. ${ }^{2}$ This was their mission: to provide Democratic candidate President Bill Clinton with a final surge of cash to send him coasting to a second term in the White House. The price of admission that night was $\$ 1,500 .^{3}$ And at least one person, Warren Meddoff, intended to help contribute much, much more.

After briefly speaking at the fundraiser, Clinton was making his way through the "crush" of attendees when Meddoff handed him a business

† B.A. 1994, Washington State University; J.D. Candidate 1999, University of Pennsylvania. This Comment is a criticism of people bending the rules, so I will not ask the Law Review editors for more space to express my appreciation to those who helped me with this paper-even though one footnote is not enough. The following, however, deserve my special thanks: my parents, Bob and Barb Meier; the hard-working members of the University of Pennsylvania Law Review; and the "12th Floor Torti." Lastly, to the politicians who are entrusted with leading our democracy, I offer this cautionary note from former President Ronald Reagan: "Politics is supposed to be the second oldest profession. I have come to realize that it bears a very close resemblance to the first." THE OXFORD DICTIONARY OF HUMOROUS QuOTATIONS 256 (Ned Sherrin ed., Oxford Univ. Press 1995).

1 See Investigation of Illegal or Improper Activities in Connection with the 1996 Federal Election Campaign-Part VII: Hearings Before the Senate Comm. on Governmental Affairs, 105th Cong. 251 (1997) [hereinafter Investigation of Illegal or Improper Activities Part VII] (testimony of R. Warren Meddoff, former Director of Governmental Affairs, Bukkehave, Inc.) (testifying that the fundraising dinner occurred on October 22, 1996). The 1996 general election took place on November 5 .

2 See id.

${ }^{3}$ See id. Meddoff's ticket was paid for by his employer, the American subsidiary of Bukkehave, Inc., a Danish firm that "supplies vehicles and spare parts... [to] the third world." Id. at 250-51. 
card. ${ }^{4}$ Clinton "took two [more] steps" and stopped in his tracks. ${ }^{5}$ Glancing at the card, he had read a simple message handwritten by Meddoff: "I have an associate that [sic] is interested in donating $\$ 5$ million to your campaign." The amount offered was equivalent to 3,300 additional guests rushing into the fundraiser. President Clinton immediately found Meddoff, a stranger until this point, and informed him that a staff member would be in contact. $^{\text {? }}$

Four days later, with just ten days left until the general election, White House Deputy Chief of Staff Harold Ickes called Meddoff from Air Force One to discuss the proposed contribution. ${ }^{8}$ By now, the offer became even more incredible and completely unprecedented in American politics. ${ }^{9}$ Meddoff informed Ickes that a business associate, ${ }^{10}$ Bill Morgan, was expecting a "very large sum of money" from a business deal and was willing to donate $\$ 5$ million initially and another $\$ 50$ million over the course of the next ten months. ${ }^{11}$ The catch was that Meddoff's associate wanted the contributions to President Clinton to be tax deductible. ${ }^{12}$ Ickes reportedly replied that there were "tax-favorable" ways of assisting Clinton's reelection campaign. $^{13}$

Later in the week, Ickes called again from Air Force One and informed Meddoff that the Clinton campaign had an "immediate need for $\$ 1.5$ million within the next 24 hours." 14 Meddoff was unsure if Morgan could ob-

4 Id. at 252 .

$5 \mathrm{Id}$.

6 Id. at 251 .

7 See id. at 252 ("[T] he President asked if ... he could have another one of [the business] cards for his staff, and [said] that somebody would get in touch with me in a few days.").

${ }^{8}$ See id. (testifying that Ickes contacted Meddoff on October 26, 1996 while calling from Air Force One).

9 See id. at 274 (statement of Sen. Don Nickles) (stating that Meddoff was offering "unheard-of contributions" to Clinton's reelection campaign, and that "no one individual" has ever made such large donations to a political campaign).

${ }^{10}$ For seven years, Meddoff and Morgan were partners in a speculative-and unsuccessful-attempt to sell "pre-1940, gold-backed German loan documents," which Germany refuses to honor, to nations now owing money to Germany and seeking to offset their debts to that country. Id. at 250-51, 261, 286 (testimony of $\mathrm{R}$. Warren Meddoff, former Director of Governmental Affairs, Bukkehave, Inc.). However, despite sharing in multi-billion dollar sales contracts (if a deal was ever successful) and speaking on the phone with each other up to "five to ten times a day" for years, the two had never met in person. Id. at 258.

11 Id. at 252-53.

12 See id. at 253 ("Mr. Morgan felt that he would have a very large tax liability from [the income from which the donations would be made], and he wanted to see if any special consideration could be given to him by making this contribution to receive a tax-favorable position.").

${ }_{14}^{13}$ Id. 
tain the funds that quickly. ${ }^{15}$ Still, Meddoff requested that Ickes forward a list of where the money should be sent. ${ }^{16}$ Within hours, Ickes, from the President's plane, dictated to a White House staff member a list of four organizations to receive the $\$ 1.5$ million. ${ }^{17}$ The Ickes list was then faxed to Meddoff from the White House. ${ }^{18}$

The list that Meddoff received was a hodgepodge of organizations, ${ }^{19}$ some offering the tax haven that Morgan sought, and others not. Contributions to the two nonprofit charities on the Ickes list, Vote Now '96 and the National Coalition of Black Voter Participation ("Black Voter Coalition"), would be tax deductible. ${ }^{20}$ By law, these groups must operate exclusively for religious, educational, or similar purposes. ${ }^{21}$ Such charities are also limited in the political activities they may undertake, and are barred from engaging in political campaigning. ${ }^{22}$ Contributions to the other two organizations, the Democratic National Committee ("DNC") and the Defeat 209

15 See id.

Mr. Ickes called me, and even though [] had made it clear [that Morgan and $]$ were not expecting funds for quite a few days, he said, "[Clinton's campaign has] an immediate need for $\$ 1.5$ million within the next 24 hours." ... [A]nd I said, "I don't Id. believe [the money will be available in] 24 hours. Perhaps within $48 \ldots .$.

${ }^{16}$ See id. ("[A]nd I said, 'We don't even know where you need us to send the money or what it's for,' and [Ickes] sa[id], 'I'll get back to you ...."').

${ }^{17}$ See Investigation of Illegal or Improper Activities in Connection with the 1996 Federal Election Campaign-Part IX: Hearings Before the Senate Comm. on Governmental Affairs, 105th Cong. 95 (1997) [hereinafter Investigation of Illegal or Improper Activities Part IX] (statement of Harold M. Ickes, former Deputy Chief of Staff to the President) ("I was on Air Force One when I talked to Mr. Meddoff. The memorandum ... was dictated by me... to somebody at the White House.").

${ }^{18}$ See id. ("[The Ickes list] was typed [at the White House], and it was sent from the White House to Mr. Meddoff.").

19 The Ickes fax directed Meddoff to make contributions to the following groups: Vote Now '96, the National Coalition of Black Voter Participation, the Democratic National Committee, and the Defeat 209 campaign. See Investigation of Illegal or Improper Activities Part VII, supra note 1, at 645-47 (reporting a facsimile from Harold M. Ickes, former White House Deputy Chief of Staff to R. Warren Meddoff, former Director of Governmental Affairs, Bukkehave, Inc. that listed the name, tax status, bank account information and contact information, and requested donation amount for each group selected by Ickes to receive a contribution).

${ }^{20}$ Both organizations are I.R.C. $\S 501$ (c)(3) charities. See id. at 294 (statement of Sen. Joseph I. Lieberman). Contributions to such groups are usually tax deductible. See infra note 77 (noting that contributions to qualified charities are deductible under I.R.C. $\$ 170(\mathrm{c})$ ).

${ }^{21}$ See infra note 70 (listing the purposes for which charities may operate to qualify under I.R.C. \& 501(c)(3)).

${ }_{22}$ See infra notes 69-77 and accompanying text (discussing the limits placed on charities' political and political campaign activities). For a discussion of the difference between "political activity" and "political campaign activity," see infra note 76, noting that "political campaign activity" is a subset of "political activity." 
campaign, ${ }^{23}$ were not tax deductible, because both are classified under the Internal Revenue Code ("IRC") as groups that typically engage in significant political and political campaign activity, albeit to differing degrees. ${ }^{24}$

Meddoff claimed that later during the same day that he received the fax, Ickes, perhaps realizing the potential impropriety of listing tax-exempt charities as Clinton-friendly organizations, called and requested that the fax be shredded. ${ }^{25}$ Ickes has refuted this allegation, stating that he "did not urge [Meddoff] to destroy the document ... [to the] best of [his] knowledge."26

In the end, neither the $\$ 1.5$ million nor the other $\$ 53.5$ million was ever used to the benefit of President Clinton's campaign. ${ }^{27}$ In fact, the money may never have existed. The contributions were supposed to come from a suspect business transaction involving the sale of old railroad bonds. ${ }^{28}$

23 Defeat 209 "spearhead[ed] the opposition in California to Proposition $209, \ldots$ subsequently approved by voters, [which] prohibits race- and gender-based preferences in state hiring, contracts and college admissions." Lawrence M. O'Rourke, Fundraising Reform Ahead?, SACRAMENTO BEE, Sept. 20, 1997, at A1.

24 Political party organizations, such as the DNC, are organized under I.R.C. $\$ 527$, and such groups usually take part in substantial political campaign activity. See infra notes 85-86 and accompanying text (describing the activities in which political organizations engage). Defeat 209 was an I.R.C. $\$ 501(\mathrm{c})(4)$ organization. See Investigation of Illegal or Improper Activities Part VII, supra note 1, at 294 (statement of Sen. Joseph I. Lieberman) (noting the tax status of Defeat 209). Groups established under I.R.C. $\$ 501(c)(4)$ are social welfare organizations that typically engage in extensive lobbying on issues, but may only engage in limited political campaign activities. See infra notes $80-83$ and accompanying text (noting that social welfare groups can lobby, but are limited in their capacity to engage in political campaign activity). Contributions to either type of organization do not qualify for tax deductions. See, e.g., BRUCE R. HOPKINS, CHARITY, ADVOCACY, AND THE LAW 250, 464 (1992).

${ }^{25}$ See Investigation of Illegal or Improper Activities Part VII, supra note 1, at 255 (testimony of R. Warren Meddoff, former Director of Governmental Affairs, Bukkehave, Inc.) ("IIckes] called me and very nicely said, 'I sent you that fax in error. I shouldn't have sent it. Would you please shred it?"').

26 Investigation of Illegal or Improper Activities Part LX, supra note 17, at 94 (statement of Harold M. Ickes, former Deputy Chief of Staff to the President) (emphasis added). In a June 27, 1997 deposition, Ickes also denied instructing Meddoff to shred the facsimile, but conceded that he "may have told Meddoff that the fax was "inoperative." 3 SENATE COMM. ON GOVERNMENTAL AFFAIRS, INVESTIGATION OF ILLEGAL OR IMPROPER ACTTVITIES IN CONNECTION WITH 1996 FEDERAL ELECTION CAMPAIGNS: FINAL REPORT, S. REP. No. 105167, at 3628-29 (1998) [hereinafter FINAL SENATE REPORT ON 1996 ILLEGAL CAMPAIGN ACTIVITIES].

27 See Investigation of Illegal or Improper Activities Part VII, supra note 1, at 276 (testimony of R. Warren Meddoff, former Director of Governmental Affairs, Bukkehave, Inc.) (noting that Morgan did not contribute to Clinton's campaign).

${ }^{28}$ Morgan, of Richardson, Texas, planned to make the $\$ 55$ million contribution from a supposed $\$ 300$ million profit "from the sale of two old railroad bonds." Robert Nolin, Businessman Regrets Contribution Offer: Potential Clinton Donor Paid Price to Be a Political Player, SUN-SENTINEL (Ft. Lauderdale), Sept. 28, 1997, at 1B. Morgan claims to have sold the bonds since then, but has refused to disclose the sum he received for the historical documents. See id. 
Morgan, Clinton's supposed benefactor-to-be, was also thousands of dollars in debt to the Internal Revenue Service ("IRS"). ${ }^{29}$

This bizarre tale, revealed in the Senate hearings on alleged campaign fundraising abuses in the 1996 elections, paints a dubious picture of the American political landscape. Here, mysterious figures who were virtual strangers to President Clinton gained access to him and his closest aides by offering unprecedented contributions, provided that the donations could be routed to tax-deductible sources. Among the many questions that this story raises is how did charities such as Vote Now '96 and the Black Voter Coalition-groups that face strict limits on the political activities in which they are permitted to engage-make it onto the Ickes list and become the topic of urgent phone calls made from Air Force One during the final days before the election?

This Comment examines an alarming trend in which charities and social welfare groups have become powerful political players, yet have been able to circumvent IRC limits on nonprofit political activity and to avoid nearly all election regulations. Part I analyzes the activities of two supposedly nonpartisan, nonprofit groups, Vote Now '96 (an I.R.C. § 501(c)(3) charity) and the Citizens for the Republic Education Fund ("Republic Education Fund") (an I.R.C. $§ 501(c)(4)$ social welfare organization during the 1996 elections). ${ }^{30}$ Part II outlines the current regulation of such groups under the IRC and the Federal Election Campaign Act ("FECA"), while Part III explains how both Vote Now ' 96 and the Republic Education Fund used gaps in the law to engage in otherwise prohibited partisan endeavors.

29 See Investigation of Illegal or Improper Activities Part VII, supra note 1, at 301 (statement of Sen. John Glenn) (noting that Morgan, in 1995 and 1996, was subject to two IRS liens "totaling about $\$ 26,000 ")$. In 1988, after defaulting on a personal note, Morgan appeared in court claiming that "he could not afford an attomey ... [and] had no financial assets to have himself represented." Id. at 279 (statement of Sen. Robert G. Torricelli).

${ }^{30}$ See infra note 48 (noting that the Republic Education Fund was an I.R.C. § 501(c)(4) social welfare group). Following the 1996 elections, the Republic Education Fund "switched [its tax] status from [a] 'social welfare' groupD to the same tax status designed to fit political parties." Jeanne Cummings, "Issue Advocacy" Groups to Play Bigger Role, WaLl ST. J., Mar. 6, 1998, at A16. The Republic Education Fund's new tax status, likely reflecting an attempt by the group to "get off of the media radar screen" and "avoid trouble," "provides the same, if not better, tax benefits and clearly allows political participation." Id. The Republic Education Fund's use of the political party tax status "push[es] the envelope' of tax and campaign finance rules," and is based upon "two obscure IRS "private [letter] rulings" on which the IRS refuses to comment. Karren Gullo, IRS Rules Will Let Donors to "Civic" Groups Stay Secret, DENVER POST, Oct. 24, 1997, at A32. Some tax experts predict that the Republic Education Fund's move could set off a new trend among nonprofit groups seeking to evade IRC and Federal Election Campaign Act limits on political activity. See Cummings, supra. This possible new loophole is not examined further in this Comment. 
Part IV of this Comment proposes to close the legal loopholes allowing charities and social welfare groups to engage in unregulated political activities by requiring that any activity likely to influence an election be conducted through nonprofit political action committees ("PACs"). This plan will allow nonprofit organizations to engage in political activity and ensure that such endeavors are regulated, while imposing few burdens on the existing rights of charities and social welfare groups.

\section{THE POLITICAL UNDERWORLD OF NONPROFITS}

\section{A. Vote Now '96: The Democrats' Political Charity}

Vote Now '96, one of the nonprofit organizations on the Ickes list, offers a telling example of the extent to which the line between political campaigning and charitable endeavors has blurred. ${ }^{31}$ Vote Now ' 96 , to which Ickes directed Meddoff to contribute $\$ 250,000$, , is touted as a "nonpartisan voter registration or ... get-out-the-vote group." ${ }^{33}$ Upon closer inspection, however, Vote Now '96 seems more like a taxpayer-subsidized ${ }^{34}$ slush fund for the Democratic Party.

31 The other charity on the Ickes list, the Black Voter Coalition, could also serve as an example of politics and charitable causes intertwining.

[T] he DNC [has] acknowledged that the party gave $\$ 117,500$ to the [Black Voter

Coalition] and asked several Democratic donors to contribute directly to the group.

The coalition helped register 150,000 African American voters during the "Million

Man March" in 1995 and it worked to elect Democrats to Congress in 83 House districts during the [1996] election cycle.

Ralph Frammolino, DNC Tied to Plan to Test Gifts Limits, L.A. TIMES, Apr. 4, 1997, at Al.

${ }^{32}$ See Investigation of Illegal or Improper Activities Part VII, supra note 1, at 647 (facsimile from Harold M. Ickes, former White House Deputy Chief of Staff to R. Warren Meddoff, former Director of Governmental Affairs, Bukkehave, Inc.).

${ }^{33}$ Investigation of Illegal or Improper Activities Part IX, supra note 17, at 167 (statement of Mark F. Thomann, former Midwest Finance Director, DNC).

${ }^{34}$ Charities, such as Vote Now '96, are tax exempt, and contributions to such groups are tax deductible. See infra notes 69,77 (noting that charities are tax exempt and that contributions to such groups are tax deductible).

Both tax exemptions and tax deductibility are a form of subsidy .... A tax ex-

emption has much the same effect as a cash grant to the organization of the amount

of tax it would have to pay on its income. Deductible contributions are similar to cash grants of the amount of a portion of the individual's contributions.

Regan v. Taxation with Representation, 461 U.S. 540, 544 (1983). Because even political parties are, for the most part, tax-exempt, see infra notes 69,88 (noting that political parties are tax exempt, except for taxes imposed on some limited types of income), "taxpayer subsidized" and related terms in this Comment typically will refer only to the additional tax deductions given to charitable contributions. 
Vote Now '96 operated exclusively to increase voter turnout in "heavily Democratic" areas. ${ }^{35}$ The group's "executive director was deputy finance director of the [DNC] throughout Clinton's 1992 campaign. Its chairman was chairman of the Democratic Senatorial Campaign Committee in 199394." ${ }^{36}$ On July 12, 1996, President Clinton and the First Lady held a fundraiser for Vote Now '96 at the White House. ${ }^{37}$

Some of the [sixty] guests were wealthy donors who wanted to give money to the Democratic Party but preferred to do so quietly, either because they had business before the Government or simply wanted to avoid having their names appear on public donor lists.

The solution was simple, they were told. They could make their donations to an organization called Vote Now '96, which was ostensibly created to encourage voter turnout and, unlike the [DNC] or the Clinton-Gore campaign organization, would not be required to identify the donors or the amount of their gifts. Vote Now '96 ultimately received \$3 million in donations in the 1996 campaign. ${ }^{38}$

The Democrats probably made other attempts to steer contributors to Vote Now '96. The charity received $\$ 3,000$ from Clinton supporter and Arkansas restaurateur, Yah Lin "Charlie" Trie, ${ }^{39}$ who was later implicated in a Chinese plot to bias the outcomes of the 1996 federal election. ${ }^{40} \mathrm{~A}$ "foreign businessman," Gilbert Chagoury, who was living in Paris and "closely tied to Nigerian dictator Sani Abacha," contributed $\$ 460,000$ to Vote Now '96. ${ }^{41}$ Despite the fact that Chagoury was "not a party contributor and[, as a for-

35 Jill Abramson \& Leslie Wayne, Both Parties Were Assisted by Nonprofit Groups in 1996, N.Y. TMES, Oct. 24, 1997, at A1.

${ }^{36}$ Burying the Treasure, PLAIN DEALER (Cleveland), Nov. 10, 1997, at 10B.

37 See Abramson \& Wayne, supra note 35 (reporting that the Clinton's hosted guests for a White House dinner on July 12, 1996 to "help generate donations" for Vote Now '96).

${ }^{38} \mathrm{Id}$.

39 See Investigation of Illegal or Improper Activities Part VII, supra note 1, at 649.

40 See 2 FINAL SENATE REPORT ON 1996 ILLEGAL CAMPAIGN ACTIVTIIES, supra note 26, at 2501-05 (noting that China's government "fashioned a plan before the 1996 elections" to "influence our political process," and that China acted "to influence U.S. elections"); see also id. at 2503 (noting that Trie has been "connected to" political donations made with "foreign money"); China Bank Reportedly Sent Money to DNC Fund-Raiser, DALLAS MORNING NEws, Apr. 2, 1997, at 8A (reporting that the government-owned Bank of China "wired large sums of money" to Trie in 1995 and 1996 while he was raising funds for Clinton and the Democratic Party). Trie initially "fled to Beijing rather than testify before a Senate committee investigating campaign abuses," but subsequently returned to the United States and "surrendered to federal agents." Richard Sisk, Clinton Pal Turns Himself in, N.Y. DAILY NEWs, Feb. 4,1998 , at 16.

${ }^{41}$ Charles R. Babcock \& Susan Schmidt, Voters Group Donor Got DNC Perk, WASH. POST, Nov. 22, 1997, at Al. "Chagoury was solicited by a DNC fund-raiser ... to give to... Vote Now [']96." Id. 
eign citizen,] could not legally give to the Democrats," he was invited to a special dinner on December 21, 1996 for the 250 top donors to the DNC. ${ }^{42}$

Vote Now ' 96 was also scrutinized during the criminal investigation of charges that the DNC "swapped" contributions with Ron Carey's 1996 reelection campaign to head the Teamsters labor union.

At their heart, the swap schemes envisioned the Teamsters contributing not only to the DNC, but also to various tax-exempt organizations ....

In exchange, the DNC and various tax-exempt organizations would [illegally] contribute directly or indirectly to the election campaign of Teamsters president, Ron Carey, through an entity called the Teamsters for a CorruptionFree Union....

When all of these circumstances are considered, Vote Now '96 begins to look a lot less like a nonpartisan charity engaged in voter registration and much more like an offshoot of the Democratic Party, performing the politically valuable service of getting Democrats to the polls. However, despite the arguably partisan activities of Vote Now '96, the anonymous contributors, the foreign donors, and the limitless size of allowable contributions (complete with a tax deduction), there is still one more incredible aspect to this story. And that is the fact that possibly everything Vote Now '96 did is perfectly legal. ${ }^{44}$

${ }^{42}$ Id.; see also infra note 93 (noting that foreign nationals are prohibited by FECA from making political contributions).

43 Investigation of Illegal or Improper Activities Part IX, supra note 17, at 163 (statement of Sen. Fred Thompson).

The swap ... [was] relatively simple.... [T] donor to give $\$ 100,000$ to Ron Carey's election campaign. In return, the Teamsters [controlled by Carey] would contribute some multiple of that amount, perhaps a million dollars, out of its treasury or PAC funds to the [Democratic Party] . . . .

... In furtherance of the conspiracy in or about July 1996, the DNC determined that a foreign citizen who previously pledged to contribute $\$ 100,000$ to the DNC [but who was barred under FECA from making such a political donation] was willing to make that contribution to the Teamsters for a Corruption-Free Union.

When it was determined that the foreign citizen was an employer and, hence, under the Federal labor laws could not contribute to the Carey campaign, the foreign money was steered by the DNC to a tax-exempt organization called Vote Now 1996.

Id. at 163-64 (statement of Sen. Fred Thompson) (internal quotations omitted).

44 See, e.g., 6 FINAL SENATE REPORT ON 1996 ILLEGAL CAMPAIGN ACTIVIrTES, supra note 26, at 9529 (Minority Views) (Additional views of Sen. Joseph I. Lieberman) ("[T] The sad truth is that most of the worst behavior that occurred in the 1996 elections was legal.... [T] agents ... plainly violates the spirit of our laws. Yet [it] appears to be legal.") Aside from Vote Now '96's implication in the DNC-Teamsters-Carey swap scheme likely offering further evidence that the charity is closely tied to the Democratic Party, the alleged illegal plot to funnel contributions to Carey via Vote Now '96 is outside the scope of this Comment and is not discussed further. 


\section{B. More Nonprofits Join the Fray: The Republic Education Fund}

As a nonprofit group created to advance political interests, Vote Now ' 96 had plenty of company in 1996 . $^{45}$ Consider, for example, the following television advertisement:

Senate candidate Winston Bryant's budget as Attorney General increased 71 [percent]. Bryant has taken taxpayer funded junkets to the Virgin Islands, Alaska, and Arizona. And spent about $\$ 100,000$ on new furniture. Unfortunately, as the state's top law enforcement official, he's never opposed the parole of any convicted criminal, even rapists and murderers. And almost 4,000 Arkansas prisoners have been sent back to prison for crimes committed while they were out on parole. Winston Bryant: government waste, political junkets, soft on crime.... Call Winston Bryant and tell him to give the money back....

Most voters in Arkansas likely would assume that Bryant's Republican opponent for the U.S. Senate, Tim Hutchinson, ${ }^{47}$ produced this advertisement. Few, however, would guess that it was produced and paid for by a nonprofit social welfare organization, ${ }^{48}$ incorporated in Washington, D.C., called the Citizens for the Republic Education Fund. ${ }^{50}$

The Republic Education Fund was created on June 20, 1996, ${ }^{51}$ just in time for the 1996 elections. With neither "a staff [n]or an office," however, the social welfare group was little more than a "shell compan[y]" for Tactical Resources in American Democracy ("TRIAD"). 52 TRIAD is a suppos-

45 See 3 FINAL SENATE REPORT ON 1996 ILlEgal CAMPAIGN ACTIVITIES, supra note 26, at 3993 "'The 1996 election witnessed an unprecedented level of political activity by nonprofit groups. ... [D]uring the 1996 election cycle, nonprofit groups spent between 55 and 70 million dollars on political advocacy campaigns.").

${ }^{46}$ ANNENBERg PUBlic Policy Center of THE UNIVERSITY of PENNSYlVANIA, ISSUE ADVOCACY ADVERTISING DURING THE 1996 CAMPAigN: A CATAlOgUE 23 (1997) [hereinafter ANNENBERG].

${ }^{47}$ See id. (noting that Democratic U.S. Senate candidate Winston Bryant was opposed, and defeated, by Republican Tim Hutchinson).

${ }^{48}$ See Gullo, supra note 30 (reporting that the Republic Education Fund was an I.R.C. $\S 501(c)(4)$ social welfare group in 1996). For a discussion of I.R.C. $\S 501(c)(4)$ social welfare organizations, see infra Part II.A.2 and accompanying text.

49 See Gullo, supra note 30.

50 See ANNENBERG, supra note 46, at 23.

51 See id. Actually, the Republic Education Fund "has been through as many incarnations as a candidate's stump speech." Eliza Newlin Carney, Stealth Bombers, 29 NAT'L J. 1640,1640 (1997). The organization was originally established by Ronald Reagan as a PAC to "help bankroll his first successful presidential bid [in 1980]." Id. The Republic Education Fund operated actively as a PAC until at least 1992, and, after "a period of neardormancy, ... resurfaced at the start of the 1995-96 election cycle" as a social welfare organization. Id.

525 FINAL SENATE REPORT ON 1996 ILLEGAL CAMPAIGN ACTIVITIES, supra note 26, at 6290-91 (Minority Views). "On September 27, 1996, six weeks prior to the elec- 
edly for-profit ${ }^{53}$ consulting firm incorporated in $1996^{54}$ that routes money from "wealthy conservative donors" to Republican candidates, PACs, and nonprofit groups. 55

TRIAD is run by Carolyn Malenick, a consultant who "spent her entire professional career in conservative Republican politics." ${ }^{\text {56 }}$ In 1996, TRIAD paid political consultants to meet with "as many as 250 Republican campaigns" in order to "assess each candidate's viability ... [and] to give strategic advice." 57 Information generated from these meetings was passed to the Republic Education Fund, ${ }^{58}$ which then produced "negative attack advertising," such as the anti-Bryant advertisement, that criticized the Democratic opponents of the Republican candidates. ${ }^{59}$ The Republic Education Fund received much of the money for its attack advertisements from TRIAD, ${ }^{60}$ which in turn received large contributions from wealthy individuals who had already made the maximum legal donation to the Republican candidates who benefited from the Republic Education Fund's advertise-

tion, ... Triad entered into a formal consulting agreement with ... [the Republic Education Fund that] granted to Triad carte blanche authority to act on behalf of ... [the] organizationप." Id. at 6302-03.

${ }^{3}$ See id. at 6293 ("Triad is not a business in the conventional sense, because it charges no fees and generates no profit.").

54 See id. at 6291 (noting that TRIAD was incorporated in 1996 and "established an office on Capitol Hill").

${ }_{55}$ Abramson \& Wayne, supra note 35.

565 FINAL SENATE REPORT ON 1996 ILLEGAL CAMPAIGN ACTIVITIES, supra note 26, at 6291 (Minority Views).

${ }^{57}$ Id. at 6295.

58 See id. at 6304 ("Both the content of the [Republic Education Fund's] advertising and the determination of where to air advertising was clearly influenced by [the consultants'] conversations with the candidates and the campaigns.").

59 Id. (stating that the candidates benefiting from such negative advertising "were the same candidates for whom Triad had solicited contributions and advised on campaign and fundraising strategy"). A Senate investigation concluded that the Republic Education Fund's advertisements were not FECA-regulated "coordinated expenditures," because the Republican candidates did not "direct] the substance or location of [the Republic Education Fund's] issue advocacy expenditures" and had only "abstract" communication with TRIAD. 3 id. at 4008 . See generally 2 U.S.C. $\$ 441 \mathrm{a}-(\mathrm{a})(7)(B)(i)$ (1994) (stating that an expenditure "by any person in cooperation, consultation, or concert, with, or at the request or suggestion of, a candidate... shall be considered to be a contribution to such candidate"); 11 C.F.R. $\S$ 109.1(b)(4)(i)(A) (1998) (stating that an expenditure is a contribution to a candidate if it is based on information given by the candidate "with a view toward having an expenditure made").

${ }^{60}$ See 5 FINAL SENATE REPORT ON 1996 ILLEGAL CAMPAIGN ACTIVITIES, supra note 26, at 6308 (Minority Views) (noting that the Republic Education Fund "was entirely financed by Triad from its creation through September 1996"); see also id. at 6307 (noting that "Triad and ... [the Republic Education Fund] were largely financed by a single backer," who is "suspected" to be Robert Cone, a businessman who supports conservative causes). 
ments. ${ }^{61}$ Even the Mafia would be impressed by this money laundering operation.

In 1996, the Republic Education Fund-which was granted its "taxexempt status ... after it told the [IRS that] it would not spend money to influence elections",62 - flooded " $\$ 4$ million in[to] more than a dozen congressional districts... [for] forceful 'issue' advertisements that left [Democratic] candidates wondering what had hit them." ${ }^{, 63}$ Over $\$ 300,000$ was spent in Little Rock and Jonesboro, Arkansas alone to help Hutchinson defeat Bryant. ${ }^{64}$ As with Vote Now '96, the Republic Education Fund did not have to disclose its donors, could accept unlimited contributions, and could receive foreign money. ${ }^{65}$

\section{NONPROFITS AND THE LAW}

The activities of groups like Vote Now '96 and the Republic Education Fund are arguably legal due to loopholes in the IRC and, ultimately, in FECA. For the purposes of this Comment, there are three types of nonprofit organizations: charities (formed under I.R.C. $\S 501(c)(3)$ ); social welfare groups (formed under I.R.C. $\S 501(\mathrm{c})(4)$ ); and political organizations (formed under I.R.C. § 527). As indicated previously, Vote Now '96 was an I.R.C. $\S 501$ (c)(3) charity; ${ }^{66}$ the Republic Education Fund was an I.R.C. $\S 501(\mathrm{c})(4)$ social welfare group in $1996 ;{ }^{67}$ and the DNC, a political party, is an I.R.C. $\$ 527$ political organization. ${ }^{68}$

61 See id. at 5982 ("[S]everal Triad donors had contributed the legal maximum in "hard dollars' to candidates who benefited from advertisements run by Triad's tax-exempt organization[.").

62 Gullo, supra note 30.

63 Carney, supra note 51, at 1640. For a discussion of political "issue advertisements," see infra note 103 and accompanying text, noting that "issue advocacy" is used "as a ruse for partisan politicking."

${ }^{64}$ See ANNENBERG, supra note 46, at 23 ("[T] $\$ 300,000$ worth of television advertisements attacking Democratic Senate candidate Winston Bryant. The media campaign ran in late October in Little Rock and Jonesboro.").

${ }^{65}$ See infra notes 102-07 and accompanying text (noting that the Republic Education Fund's advertisements are considered to be "issue advocacy" that is not subject to election limits); see also infra Part II.B (discussing the FECA requirements for political campaign activity).

\footnotetext{
See supra note 20 (noting Vote Now '96's tax status).

67 See supra note 48 (noting the Republic Education Fund's tax status).

68 See supra note 24 (noting the DNC's tax status).
} 


\section{A. Nonprofits and the IRC}

\section{Charities}

The IRC offers a series of tradeoffs for the three categories of taxexempt nonprofit groups. ${ }^{69}$ Charities must operate exclusively for limited and defined functions, such as for charitable, religious, or educational purposes. $^{70}$ Charities are also restricted in at least three other ways: such groups cannot operate to the benefit of a specific individual; ${ }^{71}$ no "substantial part" wise attempting ... to influence legislation;",73 and no charity may "participate in, or intervene in... any political campaign on behalf of (or in opposition to) any candidate for public office."74

The political limitations on charities, then, fall into two categories. Charities are confronted with an absolute bar against taking part in political campaign activity, which the IRC defines as participating in a campaign on behalf of or in opposition to a political candidate. ${ }^{75}$ Not all political activity, however, rises to the level of campaign activity. ${ }^{76}$ As long as such actions are not substantial, charities may engage in political (but noncam-

${ }^{69}$ See, e.g., HOPKINS, supra note 24, at 6 (noting that charities, social welfare groups, and political organizations are three categories of tax exempt, nonprofit groups).

${ }^{70}$ See I.R.C. $\$ 501(c)(3)$ (1994) (noting that charities must be "operated exclusively for religious, charitable, scientific, testing for public safety, literary, or educational purposes, or to foster national or international amateur sports competition . . ., or for the prevention of cruelty to children or animals").

${ }_{72}$ See id. (prohibiting charities from operating for the benefit of a specific individual).

$72 \mathrm{Id}$

73 Id. The Supreme Court has found that "political propaganda" refers to a full range of advocacy. See Meese v. Keene, 481 U.S. 465, 477 (1987) (noting that propaganda may be "slanted, misleading speech that does not merit serious attention" or advocacy that is "completely accurate and merit[s] the closest attention and the highest respect").

74 I.R.C. $\$ 501(\mathrm{c})(3)$. The limits placed on I.R.C. $\$ 501(\mathrm{c})(3)$ groups prevent charities from becoming "action organizations." 26 C.F.R. $\S 1.501$ (c)(3)-1(c)(3) (1998) (stating that a charity is not operated exclusively for an exempt purpose if it is an action organization). A group is an "action organization" if a "substantial part of its activities is attempting to influence legislation by propaganda or otherwise;" "it participates or intervenes, directly or indirectly, in any political campaign on behalf of or in opposition to any candidate for public office;" or "[i]ts main ... objectives may be attained only by legislation or defeat of proposed legislation" and it "advocates" these "objectives" instead of "engaging in nonpartisan analysis ... and making the results thereof available to the public." Id.

75 See HOPKINS, supra note 24, at 394 (defining political campaign activity under the IRC as participating or intervening in a political campaign on behalf of, or in opposition to, a candidate for public office).

${ }^{76}$ See id. at 408 ('The concept of 'political activity' is broader than the concept of 'political campaign activity.' That is, the political campaign intervention limitation applies only upon the occurrence of a particular, defined subset of political activity."). 
paign) activities like lobbying to influence legislation. In return for following these limitations on political and political campaign activity, charities have the benefit of their donors receiving a tax deduction for contributions, which encourages donations. ${ }^{77}$

\section{Social Welfare Groups}

Social welfare groups, in contrast to charities, need only be "primarily engaged in promoting in some way the common good and general welfare of the people of the community." ${ }^{\text {" }}$ Consequently, such groups usually do not receive the tax deduction benefits that charities typically enjoy. ${ }^{79}$ Social welfare organizations, however, have greater leeway in the political activities they may undertake. ${ }^{80}$ The primary mission of a social welfare group, for instance, may be to lobby on legislative issues, ${ }^{81}$ something that no substantial part of a charity's activities may constitute.

"The promotion of social welfare does not include direct or indirect participation or intervention in political campaigns on behalf of or in opposition to any candidate for public office. ${ }^{, 82}$ Because I.R.C. $\S 501(c)(4)$ nonprofit organizations only need be "primarily" engaged in social welfare, however, social welfare groups-unlike charities-are not completely barred from engaging in political campaign activities. ${ }^{83}$ Instead, any politi-

77 See I.R.C. \& 170(c) (allowing federal income, estate, and gift tax deductions for contributions to qualified charities).

7826 C.F.R. $\$ 1.501(\mathrm{c})(4)-1(\mathrm{a})(2)(\mathrm{i})$.

79 See HOPKINS, supra note 24, at 433 ("A social welfare organization ... cannot attract charitable contributions that are deductible for income, gift, and estate tax purposes."). But, "[a] social welfare organization will qualify for exemption as a charitable organization if it falls within the definition of charitable ... and is not an action organization." 26 C.F.R. $\$ 1.501(c)(4)-1(a)(2)(i)$. For a description of "charitable" and "action organization," see supra notes 70,74 .

${ }^{80}$ See HopkINS, supra note 24, at 433 ("[O]ne trade-off between [charities and social welfare groups] is a somewhat greater scope of permissible political campaign activities as opposed to deductible contributions as a source of revenue.").

An organization that is organized and operated to inform the public by educational methods on a subject of public interest and concern may be exempt under section 501(c)(4) of the Code even though the subject evokes controversy and even though the organization advocates a particular viewpoint and seeks changes in law to reflect such viewpoint.

Rev. Rul. 68-656, 1968-2 C.B. 216.

${ }^{81}$ See HopkIN, supra note 24, at 250 ("A social welfare organization may engage in any type of lobbying effort, both direct and grass roots, as long as its primary purpose is the advancement of social welfare.").

82 26 C.F.R. § 1.501(c)(4)-1(a)(2)(ii).

83 See, e.g., Rev. Rul. 81-95, 1981-1 C.B. 332 ("Although the promotion of social welfare ... does not include political campaign activities, the regulations do not impose a complete ban on such activities for section 501 (c)(4) organizations."). 
cal campaign expenditure of a social welfare group is subject to the same tax that would apply to certain income of I.R.C. $\S 527$ political organizations. ${ }^{84}$ Furthermore, political campaign activity of a social welfare group must satisfy the FECA regulations, as outlined in Part II.B.

\section{Political Organizations}

Political organizations include any group "organized and operated primarily for the purpose of directly or indirectly accepting contributions or making expenditures" 85 to "influence the selection, nomination, election, or appointment of any individual" for public office. ${ }^{86}$ As previously indicated, contributions to political organizations are not tax deductible, ${ }^{87}$ and some limited types of income of such groups are subject to taxation. ${ }^{88}$

\section{B. Nonprofits and FECA}

Almost all federal political campaigning-whether by political organizations, social welfare groups, or others-is in some way subject to the Federal Election Campaign Act. ${ }^{89}$ FECA, "landmark legislation" passed by Congress in the 1970s, was intended to "resolve, once and for all, the inequities and abuses of the political finance system." Among other things, FECA places limits on the size of political campaign contributions, ${ }^{91}$ re-

${ }^{84}$ See I.R.C. $\$ 527(f)(1)(1994)$ (requiring that any political campaign expenditure of I.R.C. $\$ 501(\mathrm{c})(4)$ nonprofit organizations be "subject to tax ... as if it constituted political organization taxable income"); see also infra note 88 (noting that some gross income of political organizations is taxable).

85 I.R.C. $\$ 527(e)(1)(1994)$.

86 Id. $\$ 527(\mathrm{e})(2)$.

87 See HOPKINS, supra note 24, at 464 ("[I]ndividual donors are not entitled to claim a tax credit for contributions to political organizations.").

${ }^{88}$ See I.R.C. $\$ 527$ (b)-(c) (imposing a tax on political organizations for gross income, excluding exempt function income such as contributions or membership dues received, above allowable deductions).

${ }^{89}$ FECA exempts some minor activities from its requirements, such as allowing voluntary itemized reporting requirements for small political campaign contributions. See, e.g., 2 U.S.C. \$ 434(b)(3) (1994) (granting discretion to political committees to identify sources that contribute an aggregate amount of $\$ 200$ or less within a calendar year).

90 ANTHONY CORRado, CREATIVE CAMPaigning: PACS AND tHe PRESIDENTIAL SELECTION PROCESS Xiii (1992).

91 See 2 U.S.C. \$ 441 a (1994). 
quires regular disclosure of political contributions and expenditures, ${ }^{92}$ and bars foreign citizens from making political contributions. ${ }^{93}$

\section{NONPROFITS AND LEGAL LOOPHOLES}

\section{A. Fissures in the Law}

Due to loopholes in the IRC and FECA, charities and social welfare groups are able to engage in partisan activities, yet argue that their actions are nonpolitical. Vote Now ' 96 claimed, for example, that it really was a nonpartisan charity and simply engaged in the socially valuable function of ensuring that historically disenfranchised minorities are able to vote. ${ }^{94}$ The facts that the group registered Democrats and helped to get them to the polls, was headed by former Democratic Party officials, benefited from a White House fundraiser, and received large contributions steered to the group by the DNC were, according to Vote Now '96, indirect consequences of its taxpayer-subsidized, "nonpartisan" mission to increase minority voter turnout. 95

${ }^{92}$ See id. $\$ 434(a)(4)$ (requiring "[a]ll political committees other than authorized committees of a candidate" to file, among other things, "monthly reports in all calendar years which shall be filed no later than the 20th day after the last day of the month").

93 See id. \$ 441e (prohibiting foreign nationals from making political contributions). A possible loophole may exist, however, that allows foreigners to make "soft money" contributions to federal political party committees. See Bruce D. Brown, Alien Donors: The Participation of Non-citizens in the U.S. Campaign Finance System, 15 YALE L. \& POL'Y REV. 503, 516 (1997) ("The use of 'soft money' . . is . . . essentially unconstrained by FECA, suggesting that foreign nationals may be able to make [soft money] contributions to the national political parties ...."). For a discussion of soft money, see infra note 152, noting that soft money is not subject to FECA regulations, yet often is used to influence federal elections. For a discussion of Congress's intent to bar foreign soft money contributions, see infra note 199, noting Congress's intent to prohibit foreign contributions from having any impact on U.S. elections.

94 See Abramson \& Wayne, supra note 35 (quoting a Vote Now '96 attorney as stating that voter registration is the "sonly interest"" of the charity's financial supporters); Babcock \& Schmidt, supra note 41 (quoting a DNC spokesperson as stating that Vote Now '96 is "“a voter participation project of importance to the DNC . . . because of its effort to increase participation in traditional[ly] disenfranchised, low income and minority communities"'). See generally DAVD B. MAGLEBY \& CANDICE J. NELSON, THE MONEY CHASE 206 (1990) ("Another source of undisclosed campaign-related expenditures is nonprofit foundations that pursue voter registration and get-out-the-vote drives. ... Although they are in principle nonpartisan, in fact they often focus their election activities on demographic groups that have predictable partisan tendencies."); Carney, supra note 51, at 1640 ("Leaders of politically active tax-exempt groups maintain that they are educating the public and promoting legislative issues, not influencing elections.").

${ }^{95}$ See supra note 35 and accompanying text (noting that Vote Now '96 operated to increase minority voter tumout in heavily Democratic areas, but that the group claimed to be nonpartisan). 
The law supports this claim. Voter registration and turnout efforts are valid activities for a tax-exempt charity. ${ }^{96}$ Targeting certain constituencies, such as minorities, in voter registration efforts has also been found to be an appropriate charitable purpose. ${ }^{97}$

Even being the beneficiary of political party fundraisers and directed contributions does not necessarily jeopardize a nonprofit organization's charitable status. Political organizations are free to "steer donors" to nonprofit groups, provided that the political parties do not "tell the groups how and where to spend the money they collect." ${ }^{.98}$ Funds that charities receive may come from foreign sources as well. ${ }^{99}$ Finally, because charitable voter turnout efforts are considered nonpolitical, groups like Vote Now' 96 avoid all election laws. ${ }^{100}$

On the basis of the criteria listed above, Vote Now ' 96 emerges with a clean slate. Apparently, the IRC and FECA need not follow common sense-or at least "common suspicion"-that a group headed by Democrats, funded by Democrats, and benefiting Democrats is a Democratic organization. Provided that Vote Now '96 engaged in the "nonpartisan" activity of registering voters, and was not overtly controlled by the Democratic Party, it apparently satisfied the requirements of I.R.C. $\S 501$ (c)(3) to qualify as a nonprofit group. Even though Vote Now '96 virtually operated as a Democratic Party subsidiary, its voter registration efforts were taxpayersubsidized and unregulated by FECA.

The legal loophole discovered by Vote Now '96, in many ways, is but a slight fissure compared to the gaping crack that allowed the Republic Education Fund to produce its "nonpolitical" television spots. As far as the IRC and FECA are concerned, this group's advertisement about the governmentwasting, junket-taking, rapist-paroling, Democratic candidate Winston Bry-

${ }^{96}$ See, e.g., I.R.C. $\$ 4945(f)$ (1994) (authorizing nonpartisan voter registration drives by tax-exempt organizations as a permissible exempt activity). Under I.R.C. $\$ 4945(f)(5)$, voter registration efforts are considered nonpartisan for tax purposes if

contributions ... [to fund the] drives are not subject to conditions that they may be used only in specified States, possessions of the United States, or political subdivisions or other areas of any of the foregoing, or the District of Columbia, or that they Id. may be used in only one specific election period.

97 See, e.g., Priv. Ltr. Rul. 95-40-044 (Oct. 6, 1995) (authorizing a charity's intention to register "large numbers of female voters, particularly in minority communities" as a proper activity).

98 Abramson \& Wayne, supra note 35.

99 See, e.g., Babcock \& Schmidt, supra note 41 (noting that foreigners "may legally contribute to nonprofit groups").

${ }^{100}$ See supra note 96 (noting that a qualified voter registration drive is a permissible charitable activity). 
ant had as much to do with the campaign for a U.S. Senate seat as would a commercial for Arkansas chickens. ${ }^{101}$ This fact speaks to a larger problem that permeates our campaign system, which is the use of "issue advocacy" ${ }^{102}$ as a ruse for partisan politicking. ${ }^{103}$

Here are the "magic words" for regulated advocacy ${ }^{104}$ : " "vote for,' 'elect,' 'support,' 'cast your ballot for,' 'Smith for Congress,' 'vote against,' 'defeat,' [and] 'reject."' 105 According to the Supreme Court in Buckley $v$. Valeo, words and phrases similar to these must be used in order for a message to be subject to FECA's regulations on "express advocacy" political campaigning. ${ }^{106}$

The fundamental difference between express and issue advocacy is that express advocacy - a message that specifically endorses the election or defeat of a candidate-is regulated by FECA, while issue advocacy-a message that often criticizes a candidate, but does not encourage an action on the part of the voter-is usually not. The Court, in an indirect admission that this standard would be confusing in practice, acknowledged that express advocacy and issue advocacy are virtually indistinguishable in many circumstances, even though only express advocacy is regulated by FECA. ${ }^{107}$

${ }^{101}$ See supra text accompanying note 46 (quoting the Republic Education Fund's antiBryant ad).

${ }^{102}$ See Buckley v. Valeo, 424 U.S. 1, 42 (1976) (permitting the "discussion of issues and candidates" without necessarily becoming subject to limits on express advocacy); see also ANNENBERG, supra note 46, at 3 ("Issue advocacy describes a communication to the public whose primary purpose is to promote a set of ideas or policies.").

${ }_{103}$ See, e.g., ANNENBERG, supra note 46, at 3 ("To the naked eye, ... issue advocacy ads are often indistinguishable from ads run by candidates. But in a number of key respects, they are different. Unlike candidates, issue advocacy groups face no contribution limits or disclosure requirements. Nor can they be held accountable by the voters on election day.").

104 Id. at 4.

105 Buckley, 424 U.S. at 44 n.52.

106 See id. at 44 (noting that FECA limits on express advocacy "must be construed to apply only to expenditures for communications that in express terms advocate the election or defeat of a clearly identified candidate for federal office"); see also ANNENBERG, supra note 46 , at 3 ("Express advocacy describes a communication to the public whose primary purpose is to advocate the election or defeat of a candidate."). But see FEC v. Furgatch, 807 F.2d 857, 864 (9th Cir. 1987) (nuling that an anti-President Jimmy Carter advertisement, which cautioned voters "Don't let him do it," was express advocacy despite the absence of "magic words" in the ad).

107

[T] dise distinction between discussion of issues and candidates and advocacy of election or defeat of candidates may often dissolve in practical application. Candidates, especially incumbents, are intimately tied to public issues involving legislative proposals and governmental actions. Not only do candidates campaign on the basis of their positions on various public issues, but campaigns themselves generate issues of public interest.

Buckley, 424 U.S. at 42. 
The Court's decision in Buckley has opened the floodgates for vicious, partisan attacks that are free from election limits. As long as words such as "vote against" or "defeat" are not used, nonprofit organizations are considered to be engaged only in "issue advocacy," and not FECA-regulated political campaigning, when they sponsor advertisements such as the Republic Education Fund's anti-Bryant ad. ${ }^{108}$

This is one instance where a word or two can make a big difference. Because express advocacy is political campaign activity, a social welfare organization sponsoring such a message is subject to the set of restrictions previously discussed: first, that I.R.C. $\S 501(c)(4)$ nonprofit organizations primarily operate for a purpose unrelated to political campaign activity; ${ }^{109}$ second, FECA's regulations, such as reporting requirements, that apply to almost all political campaign activity; ${ }^{110}$ and third, the IRC provision that

108 As nonprofit corporations, charities are subject to FECA's prohibition against corporate political campaigning. See 2 U.S.C. $\$ 441$ b (1994) ("It is unlawful for . . . any corporation ... to make a contribution or expenditure in connection with [a federal election] . ..."). Under Federal Election Commission ("FEC") regulations, the bar against corporate political campaigning is violated if a corporation's communication, "when taken as a whole and with limited reference to external events, such as the proximity of the election, could only be interpreted by a reasonable person" as advocating the election or defeat of a candidate. 11 C.F.R. $\S 100.22$ (b) (1998) (emphasis added). This "reasonable person" test does not require that "magic words" be used in order for a corporation to be found in violation of the 2 U.S.C. $\S$ $441 \mathrm{~b}$ prohibition against corporate express advocacy. See Scott E. Thomas, Hot lssues-Have the Courts Cooked the FECA?, in CORPORATE POLITICAL ACTIVITIES 1998: COMPLYING WITH CAMPAIGN FINANCE, LOBBYING AND ETHICS LAWS 547, 549-50 (1998) (noting that the FEC uses a "reasonable person approach" that does not require "magic words" to enforce $\S 441 b)$. Under this standard, the Republic Education Fund's anti-Bryant advertisement arguably could be considered express advocacy in violation of FECA's prohibition on corporate political campaigning. The FEC's "reasonable person" standard, however, has been declared unconstitutional by a number of courts. See id. at 550 (noting that the "[First] and [Fourth] Circuits clearly will not enforce the FEC's 'reasonable person' 'express advocacy' definition," and that "[a] district court in the [Second] Circuit recently ruled [that] the FEC's 'express advocacy" definition was impermissible"). The standard has also been criticized as "defining express advocacy through external events and the perception of others," which is "precisely" what the Buckley Court rejected when ruling on other provisions of FECA. Bradley A. Smith, Soft Money, Hard Realities: The Constitutional Prohibition on a Soft Money Ban, $24 \mathrm{~J}$. LEGIS. 179, 190 (1998). Putting aside issues of the constitutionality of the "reasonable person" standard, the rule's effectiveness is highly questionable if an incorporated social welfare organization like the Republic Education Fund can spend millions of dollars on advertisements that any reasonable person would view as attacking Democratic candidates and still not be cited for any violations of FECA.

109 See supra notes 78-84 and accompanying text (noting that a social welfare group must be engaged primarily in promoting the public good and that political campaigning is not considered to be such a purpose).

${ }^{110}$ See supra Part II.B (discussing examples of the FECA's requirements for political campaign activity). 
any political campaign expenditure by a social welfare group is subject to taxation. ${ }^{111}$

Absent the magic words, though, a nonprofit organization may pay for an advertisement that looks suspiciously partisan, label it "issue advocacy," and avoid all limits on political campaign activity imposed by the IRC or FECA. In fact, the Republic Education Fund did just that. The group was created less than seven months before the 1996 general election, and the only "primary activity" it engaged in - likely the only activity it engaged in at all—was producing advertisements attacking Democrats. ${ }^{112}$ For the Republic Education Fund, bumping off (electorally speaking) Democratic candidates was its means of promoting the public good, and all of this was done outside the scope of the election laws.

\section{B. The Nonprofit Political Incentive}

As the IRC and FECA now stand, an incentive exists for political parties and candidates to channel activities that they would otherwise pay for out of their own campaign coffers to nonprofit groups. Taxpayers help pay for all activities of an I.R.C. $\S 501(c)(3)$ nonprofit organization provided that the charity's "political" activity, which is often narrowly defined, ${ }^{113}$ is not substantial and it obeys the political campaign prohibition. For both charities and social welfare groups, then, independent political activity that does not rise to the level of political campaigning is unregulated by FECA, enabling nonprofit organizations to accept limitless contributions, even from foreign nationals, without having to comply with disclosure requirements.

\section{Nonprofits and Politics: An Inevitable Mix?}

Serving as the "political equivalent of Swiss bank accounts," charities and social welfare groups are now secret havens where political parties and candidates stash unlimited contributions and foreign money received from

111 See supra notes 84,88 and accompanying text (noting that the political campaign expenditures of social welfare groups are subject to the same taxes that apply to some limited types of political party income).

112 See 5 FINAL SENATE REPORT ON 1996 ILLEGAL CAMPAIGN ACTIVITIES, supra note 26, at 6301 (Minority Views) (noting that the Republic Education Fund "has [n]ever engaged in any service or activity other than paying for the production and airing of political advertising").

For example, with minimal requirements, "political" activity does not include even voter registration drives in targeted communities. See supra notes $96-97$ and accompanying text (noting that voter registration drives, including those in targeted communities, are nonpartisan activities in which a charity or social welfare group may engage). 
anonymous donors. ${ }^{114}$ Often directed by professional consultants, these nonprofit groups, camouflaged behind virtuous sounding names, such as Citizens for the Republic Education Fund, ${ }^{115}$ run the "shadow" campaigns" come with a barrage of negative advertisements during the waning days of a campaign and after the actual candidates emptied their own coffers.

Even if attempts are made to plug the legal loopholes, the odds are stacked against efforts to prevent nonprofit organizations from jumping into the political morass. Many of these groups are phantom organizations that live and die by elections. ${ }^{117}$ There is little way to police their actions until after the debates are over, the ballots are counted, and the winners' bags are packed for Washington, D.C. ${ }^{118}$

\footnotetext{
${ }_{115}^{114}$ Abramson \& Wayne, supra note 35.
}

[Nonprofit groups] who market their agendas to voters have come to realize that the name of the messenger is at least as important, if not more so, than the ideas for sale.... Often, the names bear little conviction to what's being communicated, or are so innocuous as to give no hint to who or what is behind them.

Ken Foskett, Tax Exempts-The Hidden Force: An Interest Group by Any Other Name. . . Might Not Succeed, ATLANTA J., May 31, 1998, at A8.

116 Lance Gay, Loopholes Gape for Elections in 2000, PLAIN DEALER (Cleveland), Oct. 24,1997 , at $12 \mathrm{~A}$.

117 The social welfare group Citizens for Reform offers a telling example of the short life span of many nonprofit organizations apparently organized with the sole purpose of influencing elections. Citizens for Reform was headed by Peter Flaherty, a "conservative Republican activist" who "also [ran] the Conservative Campaign Fund" and was "chairman of Citizens for Reagan." ANNENBERG, supra note 46, at 21. The group was founded in May 1996, and, like the Republic Education Fund, was a client of TRIAD. See id. (describing the activities of Citizens for Reform). Citizens for Reform lay dormant, however, until October 11, 1996, "when it opened a bank account." Abramson \& Wayne, supra note 35. "In the next 20 days, ... the group ... received $\$ 1.6$ million from Triad donors in 12 bank transactions." Id. By the general election, on November 5, 1996, Citizens for Reform spent $\$ 2$ million on advertisements such as the following: "Who is Bill Yellowtail? He preaches family values, but he took a swing at his wife. And Yellowtail's explanation? He 'only slapped her.' But her nose was broken." ANNENBERG, supra note 46, at 4. This issue advocacy advertisement was "cited by political analysts as tipping a tight race" in favor of the Republican running against

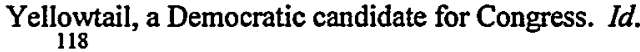

[E]nforcement [by the I.R.S. against nonprofit groups engaging in prohibited political activity] is based largely upon annual information returns filed by exempt organizations themselves. Given the relatively brief existence of the [nonprofits], by the time the I.R.S. ha[s] the information in hand, it [i]s often too late to respond effectively. If the organization ha[s] not already ceased operating, all the I.R.S. c[an] do in response to violations [i]s to revoke the organization's exempt status. Deductions taken for donations to [charitable] organization[s] before revocation cannot be retroactively disallowed.

Laura Brown Chisolm, Sinking the Think Tanks Upstream: The Use and Misuse of Tax Exemption Law to Address the Use and Misuse of Tax-Exempt Organizations by Politicians, 51 
Government watchdog agencies, such as the IRS or the Federal Election Commission ("FEC") are more like toothless Chihuahuas when it comes to supervising nonprofit organizations. Monitoring tax-exempt organizations is "something of a sideline"119 for the IRS since it rarely results in any money being paid into the Treasury. ${ }^{120}$ The FEC, the "independent agency ... with the exclusive authority to 'administer, seek to obtain compliance with, and formulate policy with respect to' the [FECA],"121 is notoriously overworked and has its hands full just trying to keep track of the groups that are allowed to engage in political campaign activity. ${ }^{122}$ As presently organized, the agency cannot effectively police nonprofit organizations that, for the most part, are supposed to be outside of FECA's regulatory purview.

The "general lack of oversight" by the IRS and the FEC has so troubled many nonprofit organizations that these groups have "asked Congress to provide more controls, lest bad charities [and social welfare groups] effectively drive out the good ones-or dissuade people from supporting

U. PITT. L. REV. 577, 593 (1990) (footnote omitted); see also George Rodrigue, For America's Nonprofit Sector, the Watchdog Seldom Barks, NIEMAN REP., Mar. 22, 1998, at 50, 56 (noting that when journalists attempted to investigate the activities of nonprofit groups like the Republic Education Fund in 1996, they "could learn precious little" because the nonprofit groups' "tax returns [were] not due until months after [the] election"); infra note 122 and accompanying text (discussing the FEC's ineffectiveness in policing campaign abuses).

19 Chisolm, supra note 118, at 593.

${ }^{120}$ See Lobbying and Political Activities of Tax-Exempt Organizations: Hearings Before the Subcomm. on Oversight of the House Comm. on Ways and Means, 100th Cong. 222, 234 (1987) (testimony of Sheldon S. Cohen, former IRS Commissioner) ("The major function of the IRS is to bring in revenue and an exempt function is specifically designed not to bring in revenue. Therefore, no matter how you enforce it, you are not going to get enough money out of it to spit at, to put it crudely."); see also Camey, supra note 51, at 1643 ("The IRS . . lacks the staff and budget to enforce the law .... The IRS division in charge of nonprofits has had a flat budget for decades."); Rodrigue, supra note 118, at 53 ("[T] he [IRS], the only nationwide regulator of nonprofits, is overwhelmed.... [A] group [can] expect to go 50 to 100 years, statistically speaking, without an IRS audit.").

${ }^{121}$ Kenneth A. Gross, The Federal Election Commission Compliance, and Enforcement Procedures Under the Federal Election Campaign Act, in FUNDING FEDERAL POLITICAL CAMPAIGNS: PACS, CORPORATE ACITVITIES AND CONTRIBUTIONS, AND LOBBYNG LAWS 211,213 (1986) (quoting 2 U.S.C. $\$ 437 c-(b)(1)(1986)$ ).

[The FEC] has neither the will nor the means to deter wanton violators [of FECA], who sometimes ridicule openly the commission's weakness. It has interpreted the law so permissively that special interest groups may funnel money to candidates practically without limit if they wish. And those who wish to evade or violate election laws have had little to fear from the FEC. It often overrules its own staff's recommendations to investigate suspected infractions, and it can consume years resolving even a relatively simple case.

BROOKS JACKSON, BROKEN PROMISE: WHY THE FEDERAL ELECTION COMMISSION FAILED 1 (1990). 
them." 123 In this "“Wild West" of American politics, where nonprofit groups can "'get away with almost anything,",124 a new sheriff is desperately needed to replace the ineffective law enforcement by the IRS and the FEC.

\section{CliPPING NONPROFITS' POLITICAL WINGS}

\section{A. A Call for Nonprofit PACs}

"If you can't beat 'em, join 'em" may not go far as a motivational, rallying cry for revising our nation's laws, but this may be one case where the motto should apply. Allowing nonprofit organizations to engage in regulated political and political campaign activity will accomplish at least three things: nonprofit political activity will be permissible, but subject to public scrutiny and election law safeguards; agencies like the IRS and the FEC could therefore better focus on those nonprofit groups that continue to circumvent the law; and the IRC and FECA will take a step toward reality, instead of existing in a fantasy land where calling a candidate a "rapist paroler" ${ }^{\prime 25}$ or "wife beater" apolitical.

A charity that intends to engage in political activity prohibited by its I.R.C. $\S 501(\mathrm{c})(3)$ tax status is already permitted to establish an I.R.C. $\S 501(c)(4)$ social welfare subsidiary. ${ }^{127}$ The IRS only requires that a charity and its social welfare arm be separately incorporated and that contributions to the charity that are entitled to a tax deduction not be used to finance the subsidiary's lobbying or propaganda-promoting activities. $^{128}$

Aside from maintaining independent bank accounts, a charity and its lobbying arm may coordinate their efforts and engage in the activities per-

${ }^{123}$ Rodrigue, supra note 118 , at 53.

124 Jim Drinkard, "Issue Advocacy" Groups: The New Electoral Power, USA TODAY, Mar. 9, 1998, at 13A (quoting Stuart Rothenberg, a political analyst).

${ }^{125}$ See supra text accompanying note 46 (quoting the Republic Education Fund's antiBryant advertisement).

${ }_{126}^{12}$ See supra note 117 (quoting the Citizens for Reform's anti-Yellowtail advertisement).

127 See HOPKINS, supra note 24, at 250 ("A charitable organization that is operating under the substantial part test can, in general, establish an affiliated tax-exempt organization for the purpose of engaging in substantial lobbying activities.").

${ }^{128}$ See Regan v. Taxation with Representation, 461 U.S. 540, 545 n.6 (1983) ("The IRS apparently requires only that [a charity and social welfare group] be separately incorporated and keep records adequate to show that tax deductible contributions are not used to pay for lobbying."). 
mitted by their respective tax-exempt status. ${ }^{129}$ Using the lobbying subsidiary as a model, the IRC and FECA should be amended to allow both I.R.C. $\S 501(c)(3)$ charities and $\S 501(c)(4)$ social welfare groups to establish "nonprofit PACs," which would be similar (but not identical) to other federal PACs.

\section{PACs Defined}

"The term political action committees, one that does not appear anywhere in the FECA, denotes a loose category of all the committees in federal campaigns other than political party committees and the official campaign committees of candidates."130 Such PACs include "any committee, club, association, or other group of persons which receives contributions aggregating in excess of $\$ 1,000$ or which makes expenditures aggregating in excess of $\$ 1,000$ during a calendar year.,"131

Contributions by individuals to PACs are capped at $\$ 5,000$ per election. ${ }^{132}$ Primary and general elections have separate caps, allowing an individual to give $\$ 5,000$ to a PAC in each election. ${ }^{133}$ A PAC may contribute up to $\$ 1,000$ per candidate in each election, the same limit that applies to individuals, unless the organization qualifies as a multi-candidate PAC. ${ }^{134}$ To become a multi-candidate PAC, a committee must be registered as such at least six months prior to an election, receive contributions from more than fifty people, and make contributions to at least five candidates for public office. ${ }^{135}$ Multi-candidate PACs may contribute up to $\$ 5,000$ per candidate in each election. ${ }^{136}$

Other types of groups that are barred from directly taking part in political campaign activity are allowed to form PACs. Corporations and labor

129

The activities of a [PAC] that is affiliated with a charitable organization will be attributed to the charitable organization for purposes of determining the ongoing taxexempt status of the charitable organization.

... [As long as the PAC engages in political activity that is not political campaign activity,] ... a charitable organization can establish an affiliated [PAC] and not lose its tax-exempt status ....

HOPKINS, supra note 24, at 426-27.

130 FRANK J. SORAUF, INSIDE CAMPAIGN FINANCE: MYTHS AND REALITIES 100 (1992).

13111 C.F.R. § 100.5(a) (1998).

132 See 2 U.S.C. $\$ 441 \mathrm{a}-(\mathrm{a})(1)(\mathrm{C})$ (1994).

133 See 11 C.F.R. $\$ 100.2(\mathrm{~b})$-(c).

134 See 2 U.S.C. $\$ 441 \mathrm{a}-(\mathrm{a})(1)(\mathrm{A})$.

135 See id. \$ 441a-(a)(4).

136 See id. \$ 441a-(a)(2)(A). 
unions, both of which are prohibited from making political contributions from their general treasury funds, may form PACs that solicit or make political contributions through separate segregated funds ("SSFs"). ${ }^{137}$ Nonprofit groups should similarly be allowed to engage in political and political campaign activity via a political subsidiary. ${ }^{138}$

FECA permits charities and social welfare organizations to create regular and multi-candidate PACs. ${ }^{139}$ The IRC, however, effectively stands as a bar to charities creating PACs, because these groups are prohibited from engaging in political campaign activity, and any "political campaign activities of an SSF are attributed back to the charitable organization that sponsors it." 140 Similarly, the IRC restricts the ability of social welfare groups to start a PAC due to the "limit on the amount of political campaign activity in which they can engage without loss of tax-exempt status."141 Charities and social welfare groups often evade these limitations by simply establishing informal ties with like-minded PACs. ${ }^{142}$

\section{Nonprofit PAC Requirements for Political Campaign Activity}

Political campaign activity, as defined by the IRC, is any activity taken on behalf of or in opposition to a candidate for public office. ${ }^{143}$ Political campaigning includes directly contributing money to a candidate's cam-

137 See id. $\$ 441$ b-(a) (prohibiting corporations or labor unions from making political contributions); id. $\$ 441 \mathrm{~b}-(\mathrm{b})(2)(\mathrm{C})$ (permitting corporations or labor unions to form PACs by establishing "separate segregated fund[s]" that are not subject to the political contribution prohibition).

${ }^{138}$ See, e.g., Laura Brown Chisolm, Politics and Charity: A Proposal for Peaceful Coexistence, 58 GEO. WASH. L. REV. 308, 352 (1990) (arguing that charities should be permitted to establish political subsidiaries under I.R.C. $\$ 527)$.

${ }^{139}$ See HOPKINS, supra note 24 , at $426-28$ (noting that charities and social welfare groups, according to election law, can establish PACs). The FEC, in an advisory opinion, even has "sanction[ed] the concept of" the managers of a charity establishing an independent PAC in order to engage in political campaign activity without jeopardizing the charity's tax status. Id. at 427. "[T] he IRS has yet to address this matter ...." HOPKINS, supra note 24, at 427.

140 HOPKINS, supra note 24, at 491.

141 Id. at 428.

142 See Anne H. Bedlington, Loopholes and Abuses, in MONEY, ELECTIONS, AND DEMOCRACY: REFORMING CONGRESSIONAL CAMPAIGN FinANCE 69, 83 (Margaret Latus Nugent \& John R. Johannes eds., 1990) ("Some tax-exempt organizations are being misused to save money for their informally affiliated PAC, thus leaving the PAC with more money to spend on candidate contributions or independent expenditures.").

${ }^{143}$ See supra note 75 (defining political campaign activity). 
paign or engaging in express advocacy, described in Buckley as urging voters to "vote for" or "defeat" a candidate. ${ }^{144}$

At present, charities are barred from engaging in direct political campaign activity. This prohibition, therefore, prevents charities from making financial contributions for, or taking part in, express advocacy. Social welfare groups are similarly limited, but to a lesser extent. I.R.C. § 501(c)(4) nonprofit groups may engage in some political campaign activity-and, thus, make contributions for, or engage in, express advocacy-provided that such groups are primarily operated to promote the public good in some other way.

With the creation of nonprofit PACs, charities and social welfare groups could freely contribute or engage in express advocacy through nonprofit PACs. These political subsidiaries will be subject to many of the FECA requirements that apply to all other federal PACs, such as contribution limits, frequent disclosure reports to the FEC, and the prohibition against receiving foreign money. ${ }^{145}$ Funds contributed to a charity or social welfare organization will be held in separate accounts, ensuring, for example, that no tax-deductible contributions are used to finance any of a charitable, nonprofit PAC's activities. All political campaigning of I.R.C. $\S 501(c)(3)$ and $\S 501$ (c)(4) organizations will be required to be conducted through such nonprofit PACs.

\section{Nonprofit PAC Requirements for Noncampaign Political Activity}

Allowing charities and social welfare organizations to make political contributions and engage in express advocacy, does not, of course, address most of the pursuits of groups like Vote Now '96 and the Republic Education Fund. As indicated before, both of those nonprofit groups arguably could claim that their activities were already legal and that political campaign activity was avoided. ${ }^{146}$

With the existence of nonprofit PACs, Vote Now '96 and the Republic Education Fund could conduct their respective voter registration drives and issue advertisements through PAC subsidiaries. An incentive still exists, however, to run activities that do not qualify as political campaign activity through the existing charity or social welfare organization. These groups

144 See supra text accompanying note 105 (listing Buckley's examples of express advocacy).

See supra notes 91-93 and accompanying text (listing examples of FECA's requirements).

146 See supra Part III.A (noting that Vote Now '96 and the Republic Education Fund claim that their activities were not political campaigning under existing IRC and FECA regulations). 
are not managed by the Mother Teresas of the nonprofit world, after all. ${ }^{147}$ Given the option to use taxpayer-subsidized funds, ${ }^{148}$ delve into foreign money, and avoid disclosure requirements, Vote Now '96 and the Republic Education Fund likely will not alter their existing game plan anytime soon.

The solution to this dilemma is to eliminate the option available to nonprofit groups to sponsor any "political" activity outside of PACs. Using common sense and an informed understanding of the realities of contemporary politics as guideposts, anything that looks, sounds, or "walks" like political campaign activity should be expressly required ${ }^{149}$ to be conducted through a nonprofit PAC. ${ }^{150}$ Notwithstanding claims by charities and social welfare groups that their endeavors have nothing to do with elections, at a minimum, activities like voter registration drives or "issue" advertisements in which candidates are pictured or discussed should be prohibited unless conducted by a nonprofit PAC.

Applying election laws to the activities of nonprofit PACs will clip the political wings of groups like Vote Now '96 and the Republic Education Fund. Under FECA, all PACs are subject to disclosure requirements and contribution limits and are prohibited from accepting foreign money-regardless of how funds are spent. ${ }^{151}$ The "soft money" loophole, which allows federal PACs to engage in issue advocacy, voter registration and get-

${ }^{147}$ Some nonprofit groups will go to great lengths to circumvent-or break-the law. For example, in 1986, it was revealed that the National Endowment for the Preservation of Liberty, an I.R.C. $\S 501$ (c)(3) charity, had "engag[ed] in campaign efforts against members of Congress who opposed aid to the [Nicaraguan] Contras and, to add insult to injury ... allegedly financ[ed] these efforts with profits from arms sales to Iran." Chisolm, supra note 138, at 309 (footnotes omitted). See generally Rodrigue, supra note 118, at 52 ("The structure of nonprofits partly explains the problem of misuse of funds. They lack many of the checks and balances built into private businesses.").

${ }^{148}$ As previously discussed, charities, not social welfare groups, typically are the only nonprofits to receive this benefit. See supra Part II.A.2.

${ }^{149}$ Specifically defining what activities are "political" and must be conducted through a nonprofit PAC should overcome the Court's objections that general definitions of prohibited political activity may be unconstitutional. See, e.g., Buckley v. Valeo, 424 U.S. 1, 41 (1976) (noting that an "indefinite" definition of prohibited political activity that "fails to clearly mark the boundary between permissible and impermissible speech" is unconstitutional); NAACP v. Button, 371 U.S. 415, 433 (1963) ("Because First Amendment freedoms need breathing space to survive, government may regulate in the area only with narrow specificity.").

${ }^{150}$ Government agencies like the FEC or IRS could be required to develop guidelines expressly dictating what activities must be conducted through a nonprofit $\mathrm{PAC}$, with nonprofit groups free to contact these agencies for advice or approval for specific projects if any regulation seems unclear. Also, some "political" activity can be exempted from the PAC requirement, such as certain types of legislative lobbying, so that I.R.C. § 501(c)(4) social welfare groups-which are often formed for the sole purpose of engaging in the political activity of lobbying - can continue to exist, independent of a PAC.

151 See supra notes $91-93$ and accompanying text (listing examples of FECA's requirements). 
out-the-vote drives, or related activities through non-FECA-regulated state SSFs, could be closed by requiring nonprofit PACs to operate only federal accounts. ${ }^{152}$ As a result, all specifically-defined "political" activities of charities and social welfare groups will be subject to FECA, removing a primary incentive for candidates and political parties to conduct partisan activities through groups like Vote Now '96 and the Republic Education Fund.

\section{B. Keeping Wayward Nonprofits in the Political Corral}

Assuming that at least some charities and social welfare groups comply with the letter and spirit of the law by forming PACs, the government's job of monitoring the political activities of nonprofit organizations should become easier. Fundamentally, nonprofit groups will have a bright line that they know not to cross: do not engage in any prohibited political activity, except through a PAC. As a result, the IRS will not have to haggle as often about what constitutes "substantial propaganda" for a charity or whether a social welfare group is failing to operate "primarily" for the public good. The FEC will receive more paperwork in the form of regular disclosure reports from nonprofit PACs, but having ready access to the disclosed infor-

152 Soft money "refer[s] to funds that are not subject to the provisions of [FECA] but are used to influence the outcome of a federal election." CORRADO, supra note 90, at 6 . Congress created the soft money loophole in 1979, in response to criticisms that FECA

reduced the traditional role of state and local [political] party organizations in federal elections and discouraged certain party-building activities. In order to redress this grievance and increase the role of parties in federal contests, the 1979 [amendments to FECA] exempted certain state and local party activities from the act's definition of "contribution" and "expenditure." This allowed party organizations to raise and spend unlimited amounts of money for voter registration, campaign materials, getout-the-vote drives, and other activities without having to disclose these funds to the [FEC].

....

The 1979 amendments made no specific provision for the use of nonfederal soft money accounts by nonparty political committees. The use of separate nonfederal accounts by PACs is ... a result of the ambiguities of federal law rather than its particular sanctions.

Id. at 12, 121 (footnote omitted).

Unregulated get-out-the-vote drives or issue advocacy advertisements, then, are typically run through state political parties, state PACs, and nonfederal accounts of federal PACs. Because such organizations, in these cases, are subject only to state election laws, they may "receive contributions in excess of the amount permitted by federal statutes, [and] solicit funds from sources long prohibited from participating in federal elections .... They can also operate in relative secrecy because most state disclosure laws lack the rigorous requirements for public disclosure established at the federal level." Id. at 121-22. This soft money loophole can be closed, however, by requiring all nonprofit PACs to be federal (making them subject to FECA) and by prohibiting them from establishing nonfederal soft money accounts. 
mation should prove valuable to any FEC investigation of possible FECA violations by a nonprofit group.

For nonprofit organizations attempting to sponsor prohibited political activity, the sanctions are, and will remain, severe. Under the IRC, if a nonprofit organization engages in forbidden political activity, the IRS may impose "substantial excise tax penalties on errant organizations and their managers," and may "move swiftly ... to revoke the exempt status of organizations that are determined to be in 'flagrant violation' of the proscription on political expenditures."153 These penalties will remain in place, although the scope of prohibited political activity-unless accomplished through a nonprofit PAC - will be expanded. Any FECA violations by charities or social welfare groups will also be subject to the range of investigatory and prosecutorial powers possessed by the FEC. ${ }^{154}$

By thinning the herd of nonprofit groups attempting to evade the IRC and FECA, the IRS and FEC possibly can serve as the alert watchdogs they were intended to be. Any political activity by a charity or social welfare group without a PAC will be per se illegal, and subject to the arsenal of penalties both agencies possess, but use too rarely due to loopholes in the law.

\section{Seeking the Constitution's Seal of Approval}

Advocating any proposal that may be viewed as restricting the First Amendment rights of nonprofit groups is fraught with danger. This is hardly an area of the law known for its unanimity of opinion regarding what the Constitution permits. ${ }^{155}$ Debate is likely to rage on in Congress about the extent to which nonprofit groups' political activity may be limited. Forecasting the outcome of this policy crap shoot, let alone what the Court

153 Chisolm, supra note 138, at 318-19 (quoting I.R.C. $\$ 6852$ (Supp. V 1987)); see also I.R.C. $\S 4955$ (1994 \& Supp. II 1996) (imposing taxes on prohibited political expenditures of charities); I.R.C. $\$ 7409$ (1994) (allowing the IRS to seek an injunction against charities flagrantly violating political expenditure limits).

154 See 2 U.S.C. \$ 437(d) (1994).

155 See, e.g., Archibald Cox, The Case for Campaign Finance Reform, 1 GREEN BAG 2D 289, 291 (1998) ("The Supreme Court today ... [is] very much divided on [issues such as whether issue advocacy ads may be prohibited] .... And it's awfully hard to prejudge where [the Court] will come down [on these issues]."). Compare 6 FINAL SENATE REPORT ON 1996 ILLEGAL CAMPAIGN ACTIVITIES, supra note 26, at 9546 (Minority Views) (Additional views of Sen. Joseph I. Lieberman) (arguing that proposals to "forbid [nonprofit groups from] run[ning] advertisements ... identifying a candidate within 60 days of a general election or 30 days of a primary election" would "pass constitutional muster"), with Smith, supra note 108, at 192 (arguing that restricting nonprofit organizations from sponsoring issue advertisements identifying candidates within 60 days of a general election is "truly silly and blatantly unconstitutional"). 
however, that requiring nonprofit groups to engage in campaigning and other political activities only through PACs is constitutional.

\section{The Constitutionality of the Nonprofit PAC Requirement for Political Campaign Activity}

Requiring charities and social welfare groups to engage in political campaign activity, such as contributing money to candidates or taking part in express advocacy, through nonprofit PACs arguably survives constitutional scrutiny. Currently, charities are barred from directly sponsoring such activities, so the ability to form a PAC will be an unexpected boon. Social welfare groups, in effect, already form PACs when they engage in the limited political campaign activity permitted by the IRC, because such activities are typically paid for out of SSFs. ${ }^{156}$

One stumbling-block in the way of the nonprofit PAC proposal, though, is the Supreme Court's decision in FEC v. Massachusetts Citizens for Life, Inc. ("MCFL"). ${ }^{157}$ In $M C F L$, the Court held that a nonprofit group with no business activities or ties to a for-profit corporation cannot be required to engage in independent express advocacy ${ }^{158}$ through an SSF. ${ }^{159}$

Justice Brennan, the author of the MCFL Court's opinion, cited several reasons why nonprofit groups resembling "voluntary political associations"160 cannot be required to establish PACs for independent expenditures. First, "ideological" nonprofit groups do not have access to business income that might enable them to "gain [an] unfair advantage in the political marketplace."161 Because the risk of corporate financial power being used to corrupt the political process is the usual justification given for prohibiting corporations from using their general treasury funds for political purposes, requiring ideological, nonprofit groups with no business income to establish

156 See HOPKINS, supra note 24, at 427 (noting that FECA permits social welfare groups to create PACs).

157479 U.S. 238 (1986).

158 An independent expenditure is defined as "an expenditure by a person expressly advocating the election or defeat of a clearly identified candidate which is made without cooperation or consultation with any candidate, or any authorized committee or agent of such candidate ...." 2 U.S.C. $\$ 431(17)$.

159 MCFL, 479 U.S. at 263-64 (holding that a nonprofit organization cannot be required to engage in independent express advocacy through an SSF if (1) the group does not "engage in business activities"; (2) the group has "no shareholders or other persons affiliated so as to have a claim on its assets or earnings"; and (3) the group is not established or funded by business corporations or labor unions).

160 Id. at 263.

161 Id.; see also id. at 258-59 (arguing that funds available to business corporations are unrelated to the "popular support for the corporation's political ideas," while resources available to an ideological, nonprofit group reflect "its popularity in the political marketplace"). 
corporations from using their general treasury funds for political purposes, requiring ideological, nonprofit groups with no business income to establish PACs for independent political campaigning is unnecessary. ${ }^{162}$ Second, an SSF only may solicit funds from a narrowly defined class of a nonprofit group's "members," which could severely restrict the ability of some groups to raise money for political campaign activity. ${ }^{163}$ Third, Brennan argued that FECA's "extensive" organizational and reporting requirements for PACs would unconstitutionally burden nonprofit groups, such as small groups of "like-minded persons" who may seek to fund their "occasional endorsement of political candidates ... by means of garage sales, bake sales, and raffles."

$M C F L$ is far from a victory for nonprofit groups seeking to engage in unfettered political campaign activity. Under the decision, I.R.C. $\S$ 501(c)(4) organizations must still establish SSFs for nonindependent political campaigning, such as express advocacy that is coordinated with a candidate. IRC limitations on the extent of political campaign activity by charities and social welfare groups also remain in place. All social welfare organizations, including those covered by $M C F L$, must operate primarily for purposes other than political campaigning. ${ }^{165}$ Charities are similarly restricted in that they can engage in only limited political activities and no political campaigning. ${ }^{166}$ Finally, a nonprofit organization closely associated with a for-profit business, such as the Republic Education Fund's ties to TRIAD, is not protected by MCFL. ${ }^{167}$

In a number of ways, then, the nonprofit PAC requirement would provide more freedom than the current law for charities and social welfare groups to engage in political campaign activity. With the creation of nonprofit PACs, charities and social welfare groups could engage in unlimited political campaigning, but only through FECA-regulated SSFs. Furthermore, any questions raised by $M C F L$ about the constitutionality of the non-

162 See id. at 263-64 (holding that concerns about corporate wealth as a "threat to the political marketplace" are unwarranted where corporations with "features more akin to voluntary political associations than business firms" are engaged in independent political campaigning).

${ }^{163}$ See id. at 260 ("The limitation on solicitation ... means that nonmember corporations can hardly raise any funds at all ...."); see also 2 U.S.C. § 44lb-(b)(4)(A)-(C) (1994) (requiring that an SSF only solicit a corporation's stockholders and their families, the corporation's executive or administrative personnel and their families, or the members of a labor organization and their families, if the group is a membership corporation without capital stock).

164 MCFL, 479 U.S. at 254-55.

165 See supra Part II.A.2 (discussing the requirements for I.R.C. $\$$ 501(c)(4) tax status).

166 See supra Part II.A.1 (discussing the requirements for I.R.C. $\$ 501$ (c)(3) tax status).

167 See $M C F L, 479$ U.S. at 264 (stating that a nonprofit group can only make an independent expenditure without a PAC if the group is "not established by a business corporation ... and it is [the group's] policy not to accept contributions from such entities"). 
profit PAC proposal can be remedied by making slight changes to the PAC requirement or the existing laws governing nonprofit organizations.

A primary objection raised by Brennan, for instance, was that ideological, nonprofit groups should not be forced to establish SSFs for independent expenditures because such groups do not generate business income that can be used to corrupt the political process. This ruling should not be fatal to the nonprofit PAC requirement, however, because it is based on current laws that permit nonprofit groups to engage in some degree of political activity without jeopardizing their tax status.

The Court held that the political and political campaign activities of charities and social welfare groups can be restricted, due to the fact that such organizations are taxpayer-subsidized ${ }^{168}$ and benefit from the "special advantages that the State confers on the corporate form." It is is only by legislative grace that I.R.C. $\S 501$ (c)(4) tax status allows social welfare groups to participate in some political campaign activity. Congress can easily change the tax code to ban social welfare groups from taking part in any such activity, even through SSFs, ${ }^{170}$ as is the case for charities. ${ }^{171}$

From this perspective, $M C F L$ holds only that ideological, nonprofit organizations engaged in independent campaign activities permitted by their tax status cannot be required to establish SSFs. By altering the IRC to create a blanket prohibition on political campaign activity by I.R.C. $\S 501(c)(3)$ or $\S 501(c)(4)$ nonprofit groups without SSFs, the problems presented by $M C F L$ are avoided, a fact indirectly affirmed by the Court. ${ }^{172}$

A second issue raised by $M C F L$ is the solicitation limitations placed on SSFs that prevent a nonprofit group from contacting even "those persons who have ... contributed to or indicated support for the organization in the past." This constraint could fatally handicap the ability of many nonprofit groups to raise sufficient funds to "engage in political speech war-

168 See supra note 34 and accompanying text (noting that the tax-exempt status of charities and social welfare groups, as well as the tax deductibility of contributions to charities, are subsidies).

169 FEC v. National Conservative Political Action Comm., 470 U.S. 480, 495 (1985).

170 See 6 FINAL SENATE REPORT ON 1996 ILLEGAL CAMPAIGN ACTIVITIES, supra note 26, at 9546 (Minority Views) (Additional views of Sen. Joseph I. Lieberman) (arguing that nonprofit organizations can be prohibited from engaging in political campaign activity due to the government subsidies that such groups receive under their tax-exempt status).

171 See supra text accompanying note 140 (noting that the IRC bars charities from engaging in political campaigning).

See MCFL, 479 U.S. at 262 (noting that the extent to which an ideological, nonprofit group can participate in political campaign activity is ultimately limited by the group's tax status).

${ }^{173}$ Id. at 254 (citing FEC v. National Right to Work Comm., 459 U.S. 197, 204 (1982)). 
ranting the highest constitutional protection."174 Therefore, the "member" requirement and similar restrictions ${ }^{175}$ on SSF solicitations should be eliminated (or loosened, if constitutionally acceptable standards can be developed) for ideological, nonprofit PACs. ${ }^{176}$

The last major hurdle presented by MCFL is FECA's organizational and reporting requirements for PACs, discussed in detail by Justice Brennan. ${ }^{177}$ Justice Brennan warned that such mandates may chill political speech, with some nonprofit groups, "[f]aced with the need to assume a more sophisticated organizational form, to adopt specific accounting procedures, to file periodic detailed reports, and to monitor garage sales," deciding "that the contemplated political activity [is] simply not worth it." 178 It is important to note, however, that Justice Brennan's objections are not part of MCFL's holding, as they appear in the only portion of his opinion not adopted by the Court. ${ }^{179}$ In fact, at least four other Justices, led by Chief Justice Rehnquist, expressly rejected Justice Brennan's claims that such "burdens" on nonprofit groups engaged in political campaign activity are unconstitutional. ${ }^{180}$

Still, it should be obvious that the Republic Education Fund and Vote Now '96 are the types of culprits that create the need for nonprofit PACs. It is hardly going out on a limb to allege that these groups have never funded their activities through "bake sales," and it is unlikely that such organizations, run by highly sophisticated political professionals, will find FECA's requirements to be so complicated that any desired political campaign activity will be abandoned. Reasonable guidelines should be considered that will establish a level of political campaign activity that must be surpassed for an ideological, nonprofit organization to become subject to the PAC requirement. ${ }^{181}$ For groups that remain below this threshold, the usual,

174 Id. at 260.

175 See, e.g., 2 U.S.C. $\$ 441$ b-(b)(4)(B) (1994) (limiting SSFs to "[two] written solicitations for contributions during the calendar year").

176 But see MCFL, 479 U.S. at 269 (Rehnquist, C.J., concurring in part and dissenting in part) (arguing that it is constitutional to require a nonprofit group's independent expenditures to be made through SSFs that are subject to solicitation restrictions).

177 See id. at 253-55 (listing FECA requirements for PACs, such as provisions that all committees must appoint a treasurer, file reports with the FEC, and keep records of contributions).

178 Id. at 255.

179 See id. at 241.

180 See id. at 270-71 (Rehnquist, C.J., joined by White, Blackmun \& Stevens, JJ., concurring in part and dissenting in part) (arguing that Congress has the power to require nonprofit organizations to engage in independent expenditures only through $\mathrm{PACs}$ ).

181 Such guidelines will be similar to FECA's requirement that any group receiving contributions, or making political campaign expenditures, in excess of $\$ 1,000$ in a calendar year must establish a PAC. See text accompanying supra note 131 (stating that a group becomes a political committee once it receives $\$ 1,000$ in contributions or makes $\$ 1,000$ in expenditures). 
less stringent FECA regulations for political campaign activity will still apply. ${ }^{182}$

With only minor changes to the nonprofit PAC proposal, requiring charities and social welfare groups to engage in political campaign activity only through SSFs seems to satisfy any constitutional concerns. Both I.R.C. $\S 501(c)(3)$ and $\S 501(c)(4)$ organizations likely will find that the ability to make direct campaign contributions and to engage in express advocacy via PAC subsidiaries will entail much gain with little pain.

\section{The Constitutionality of the Nonprofit PAC Requirement for Noncampaign Political Activity}

The real First Amendment battleground for nonprofit PACs is the requirement that charities and social welfare groups must route all political activities-including noncampaign activities-through SSFs subject to FECA. This issue is difficult to discuss without getting sucked into a constitutional black hole, where different opinions as to what the Court will allow swirl about and frequently collide. ${ }^{183}$ In defense of the nonprofit PAC requirement, however, justifications exist for insisting that the political activities of charities and social welfare groups only be conducted by SSFs and that such a requirement is constitutional.

As discussed in Part IV.C.1, the political campaign activities of charities and social welfare groups may be restricted due to the benefits these nonprofit groups enjoy as taxpayer-subsidized corporate entities. ${ }^{184}$ The noncampaign political activity of such groups can be restricted under similar reasoning, as is illustrated by the IRC mandate that no substantial part of a charity's activity may be for propaganda purposes or for influencing legislation. ${ }^{185}$ The First Amendment should not prevent further express limits on

In $M C F L$, the nonprofit group spent almost $\$ 10,000$ to independently publish and distribute over 100,000 copies of a guide that rated candidates on anti-abortion issues. See $M C F L, 479$ U.S. at 243-44 (describing the activities of Massachusetts Citizens for Life in the 1978 elections). This appears to be the type of large-scale, independent political campaign activity that should be sufficient to make a group subject to the nonprofit PAC requirement.

182 See, e.g., 2 U.S.C. $\$ 434$ (c) (1994) (requiring "[e]very person (other than a political committee) who makes independent expenditures in an aggregate amount or value in excess of $\$ 250$ during a calendar year" to make certain disclosures about the person's donors and political campaign activities).

183 See, e.g., supra note 155 and accompanying text (noting the different opinions of two legal commentators on the constitutionality of restricting nonprofit groups' political activities).

84 See supra note 34 and accompanying text (noting that the tax-exempt status of charities and social welfare groups, as well as the tax deductibility of contributions to charities, are subsidies).

${ }^{185}$ See supra notes 71-74 and accompanying text (discussing restrictions on the political activities of charities). 
the political activities in which I.R.C. § 501(c)(3) and § 501(c)(4) organizations may engage, ${ }^{186}$ especially because an avenue remains open for such groups to take part in political activity through PACs. ${ }^{187}$ By simply expanding the IRC's existing rules against political activity to encompass such actions, the voter registration drives of Vote Now '96 and the "issue" advertisements of the Republic Education Fund can be prohibited unless a FECA-regulated SSF is used.

A second, more innovative-and speculative ${ }^{188}$-approach to regulating much of the political activity that presently escapes FECA's requirements is to expand the definition of political campaign activity set forth in Buckley v. Valeo. ${ }^{189}$ In Buckley, the Court ruled that only political speech expressly advocating the election or defeat of a candidate is subject to FECA, because a broader application of the law would create ambiguous limits as to what speech is regulated. ${ }^{190}$ The Court then listed examples of express advocacy, such as urging voters to "support" or to "oppose" a political candidate, in a footnote.

Many campaign finance reformers, who are opposed to unregulated advertisements like the Republic Education Fund's that "any reasonable person would view ... as promoting a specific candidate,"192 contend that the Court's list of words and phrases is not an exhaustive definition of express advocacy. ${ }^{193}$ In fact, legislative proposals recently have been introduced in

${ }^{186}$ See, e.g., Regan v. Taxation with Representation, 461 U.S. 540, 544-45 (1983) (noting that by limiting the political activity of nonprofit groups, "Congress has merely refused to pay for [such activities] out of public moneys"); 6 FINAL SENATE REPORT ON 1996 ILLEGAL CAMPAIGN ACTIVITIES, supra note 26, at 9546 (Minority Views) (Additional views of Sen. Joseph I. Lieberman) (arguing that nonprofit group political advocacy may be restricted due to the benefits nonprofit groups receive from their tax status).

${ }^{187}$ See generally Taxation with Representation, 461 U.S. at 553 (Blackmun, J., concurring) (arguing that it is constitutional to limit the political activities of charities due to the fact that such groups can establish SSFs to engage in otherwise prohibited political speech).

${ }^{188}$ See, e.g., Smith, supra note 108, at 184 ("'Campaign finance regulatory enthusiasts] argue that [issue] ads are intended to influence federal elections, and ... may be regulated under the Buckley framework. In fact, we have been down this road before, and the advocates of regulation are dramatically wrong.").

189 Buckley v. Valeo, 424 U.S. 1 (1976).

190 See $i d$. at 44 (ruling that "in order to preserve the [FECA] against invalidation on vagueness grounds, [the law] must be construed to apply only to expenditures for communications that in express terms advocate the election or defeat of a clearly identified candidate").

191 See id. at $44 \mathrm{n} .42$ (listing examples of express advocacy); see also supra note 106 and accompanying text (discussing Buckley's examples of express advocacy).

1926 FINAL SENATE REPORT ON 1996 ILLEGAL CAMPAIGN ACTIVITIES, supra note 26, at 9534 (Minority Views) (Additional views of Sen. Joseph I. Lieberman).

193 See id. ("[T]here is nothing in the Court's decision to suggest that ... footnote $[42$ in Buckley] defined the exclusive universe of candidate-focused speech ...."); see also Tena Jamison Lee, A Pro and Con Debate: How Much Campaign Finance Reform Do We Need?, 
Congress that would expand the universe of regulated political campaign speech to include advocacy that, in some specified way, supports or opposes a clearly identified candidate even without using "express" terms. ${ }^{194}$

Under such broader definitions of express advocacy, the political attack advertisements of groups like the Republic Education Fund are automatically subject to FECA, eliminating a primary objection to the PAC proposal that nonprofit groups should not be forced to use FECA-regulated SSFs for noncampaign (as currently defined) political activity. Opponents to these attempts to broaden the definition of express advocacy, however, "counter that the Court has defined the terms once and for all and it is ... [unconstitutional] to expand on the [Buckley] decision."195

Even if it is constitutional to require charities and social welfare groups to engage in political activity only through PACs, it is a safe bet that nonprofit groups like Vote Now '96 and the Republic Education Fund will vociferously protest the PAC requirement. Implementing such a reform likely will be similar to jabbing a stick in a hornet's nest, with angry charities and social welfare groups storming the Sunday morning political talk shows, proclaiming that their right to free speech has been filched. To borrow a phrase from Shakespeare, however, "[t]he lady doth protest too much methinks." Is Is there really anything draconian about requiring nonprofit organizations to conduct their political activities through PACs, unless these groups are purposely attempting to evade the IRC and FECA?

With nonprofit PACs in place, charities and social welfare groups may engage in unlimited political and political campaign activity as long as the federal election laws are satisfied. Vote Now ' 96 could openly advertise itself as a vote-getter for the Democratic Party, while the Republic Education Fund could sponsor "anti-liberal" advertisements until the television networks run out of available commercial space. The nonpolitical endeavors of charities and social welfare groups will not be impacted directly in any way.

All political activities of nonprofit groups will be subject to FECA, but this hardly works as a gag order on the political aspirations of charities and

HUM. RTS., Winter 1998, at 14, 15 ("[T] here is room for Congress to define with more clarity what is meant by issue advocacy and political campaigning without running afoul of the Court's real intent.")

${ }^{194}$ See, e.g., S. 25, 105th Cong. $\$ 406$ (b) (1997) (defining express advocacy as a communication "that refers to a clearly identified candidate, that a reasonable person would understand as advocating the election or defeat of the candidate, and that is made within $\mathbf{3 0}$ days before the date of a primary election ... or 60 days before a general election"); H.R. 493, 105th Cong. $\$ 251$ (b) (1997) (same).

195 Lee, supra note 193, at 15.

196 WILliaM SHAKESPEARE, HAMLET act 3, sc. 2, line 229 (John Dover Wilson ed., Cambridge Univ. Press 2d ed. 1980) (circa 1600). 
social welfare groups. Disclosure requirements, although a headache to those wishing to keep their political activities a secret, are generally thought of as critical to "deter[ring] actual corruption and avoid[ing] the appearance of corruption by exposing... [political activity] to the light of publicity."197 Nonprofit organizations that come to the political soiree should have to reveal with whom they are dancing. ${ }^{198}$ Prohibiting nonprofit groups and others from using foreign money for political purposes is similarly a less than earth-shattering reform; if anything, such a provision is probably what Congress has intended all along. ${ }^{199}$

The primary pitfall for the nonprofit PAC proposal is the contribution limit that applies to federal PACs. Although nonprofit PACs, like all federal PACs, only face spending limits when engaged in political campaign activity, FECA does restrict how much a contributor may give to a PACregardless of how the money is ultimately used. Contributions by individuals to PACs are capped at $\$ 5,000$ per election, ${ }^{200}$ a far cry from the nearly half-million dollar donation Vote Now '96 received from just one foreign supporter. ${ }^{201}$

Imposing contribution limits on nonprofit PACs engaged in political, but not political campaign, activity is severe. After all, in these cases the PAC subsidiaries would not be taking part in activities that are normally subject to FECA requirements. For this reason, a concession is in order: The size of contributions to nonprofit PACs should only be restricted when

197 Buckley v. Valeo, 424 U.S. 1, 67 (1976).

198 See, e.g., MAGLEBY \& NELSON, supra note 94, at 206 ("We propose that any person, party or foundation disclose the amount spent on any activity that could influence the outcome of a federal election, including nonpartisan registration and get-out-the-vote campaigns.").

199 See 4 FINAL SENATE REPORT ON 1996 ILLEGAL CAMPAIGN ACTIVITIES, supra note 26, at 4579 (Minority Views). "The federal law barring foreign contributions in U.S. elections is set forth in section 441e of [FECA]. Section 441e is intended to prohibit foreign money from playing any role in U.S. elections, but the statutory language is not as clear or as strong as needed and should be strengthened." Id. (emphasis added); see id. at 4580 (noting that "[c]lear legal prohibitions on [the ability of] foreign nationals" to contribute soft money for "issue ads" are "vital to keeping foreign money from influencing U.S. elections"); see also 3 $i d$. at 4471 ("[The] prohibition [against foreign nationals directly or indirectly contributing to U.S. elections] dates from 1966 legislation responding to congressional hearing revelations that Philippine sugar producers and agents of Nicaraguan president Luis Somoza contributed to federal candidates."); Stuart W. Nolan, Jr., Comment, Campaign Finance Reform: Applying the First Amendment in a Marketplace of Ideas, 6 COMMLAW CONSPECTUS 113, 119 (1998) ("FBI investigators [examining alleged campaign fundraising abuses in the 1996 elections] uncovered illegal foreign contributions of so-called 'soft money' to the [DNC]. This prompted the introduction of three additional bills from Congress proposing to make such contributions expressly illegal." (emphasis added) (footnotes omitted)).

${ }^{200}$ See text accompanying supra note 132.

201 See supra note 41 and accompanying text (discussing Chagoury's $\$ 460,000$ contribution to Vote Now '96). 
the funds are used for political campaign purposes. ${ }^{202}$ Although this is a significant adjustment, it is fair to the nonprofit groups and may be necessary for the PAC requirement to survive a constitutional challenge.

It is important to note here that a stalemate on the issue of regulating the political activities of nonprofit organizations is the practical equivalent of throwing our nation's election laws out the window. ${ }^{203}$ Without succumbing to the "Chicken Little Syndrome" (that is, arguing for reforms by frantically claiming that the "sky is falling"), it seems incredible that we now live under a system where, hypothetically, communist foreign nationals can legally make millions of dollars in anonymous contributions to a nonprofit group that targets American citizens with the goal of persuading them to support specific candidates for federal office. ${ }^{204}$ Or, perhaps more commonly, is it not a perversion of our political system when nonprofit groups become key players in political campaigns, but are immune from FECA as long as they make no direct financial contributions to the candidates and avoid terms like "vote for" or "defeat"? The nonprofit PAC requirement is an important step toward ensuring that political activities of nonprofit groups are properly regulated.

\section{CONCLUSION}

In the 1996 federal elections, "there were really two campaigns conducted"- "an 'overt' campaign and a 'covert' campaign."205 In the overt campaign, all participants abided by FECA. ${ }^{206}$ The rules of the covert campaign, however, "were utterly different."207 "In this parallel campaign, there

${ }^{202}$ Regulating these contributions can be done as easily as requiring nonprofit PACs engaged in political and political campaign activity to maintain two separate accounts: one for unlimited contributions that may be used for nonpolitical campaign purposes, and another for capped donations that may be used for either political or political campaign activities.

203 See, e.g., 5 FINAL SENATE REPORT ON 1996 ILIEGAL CAMPAIGN ACTIVITIES, supra note 26, at 7055 (Minority Views) ("It is possible ... that a single wealthy donor could influence the outcome of dozens of congressional races by channeling millions of dollars through tax-exempt organizations. If large donors are allowed to operate on that scale-and with no disclosure and no accountability - the campaign finance laws will be meaningless.").

${ }^{204}$ Does this sound preposterous? It is not. Suppose that a social welfare group called the "Communist Social Welfare Fund" is established. The Communist Social Welfare Fund, like the Republic Education Fund, would be free to accept unlimited and anonymous contributions from foreign sources. Those funds could then be used to conduct communist-oriented propaganda campaigns and voter registration drives in targeted districts.

2034 FINAL SENATE REPORT ON 1996 ILLEGAL CAMPAIGN ACTIVITIES, supra note 26, at 5983 (Minority Views).

${ }^{206}$ See id. ("In the 'overt' campaign, all contributors ... revealed their names, their occupations, and the size of their donations to the [FEC].").

207 Id. 
was no disclosure, and there were no limits on how much money could be contributed. Tax-exempt 'issue advocacy' groups and other conduits were systematically used to circumvent the [FECA]," "severely undermin[ing] our campaign finance laws and corrupt[ing] the electoral process."208 This is the political underworld in which groups like Vote Now '96 and the Republic Education Fund thrived, and "[t]here is every reason to believe that these de facto campaign[s] ... determined the outcome of some ... close [federal] races."209

Far from being an aberration of the 1996 elections, an "influx of new [nonprofit] groups" are joining Vote Now '96 and the Republic Education Fund in the political arena, sending "a clear signal that the aggressive role taken by [nonprofit] organizations in the 1996 campaign[s] likely will be repeated, or expanded," in future elections. ${ }^{210}$ These charities and social welfare groups, like those in 1996, will "spen[d] millions of dollars on activities designed to affect the outcome of federal elections ..., yet none [will] disclose[] their contributions or expenditures to the public or acknowledge[] that [FECA] applie[s] to their operations."211 Such secret political activity of nonprofit organizations is the Achilles' heel of federal campaign finance laws and blatantly violates the purposes for which charities and social welfare groups were created.

This Comment proposes that nonprofit groups should be required to conduct their political activities through PACs. The nonprofit PAC requirement is a critical reform that will help plug loopholes in the IRC and FECA that permit taxpayer-subsidized charities and social welfare groups to engage in unregulated political activity. Confronted with this proposal, groups like Vote Now '96 and the Republic Education Fund will no doubt "defend their behavior by waving the First Amendment as if it were some kind of Constitutional hall pass, where having the right to speak freely justifies any and all behavior exercised under it, no matter whom it hurts."212 Congress should not give in to these empty arguments. Nothing less than the integrity of our democracy is at stake.

208 Id. at 5983-84 (Minority Views).

209 Id. at 5983.

${ }^{210}$ Cummings, supra note 30.

2114 FINAL SENATE REPORT ON 1996 ILLEGAL CAMPAIGN ACTIVITIES, supra note 26, at 5926 (Minority Views).

${ }^{212} 6$ id. at 9552 (Additional views of Sen. Joseph I. Lieberman). 